\title{
Securities Litigation Risk for Foreign Companies Listed in the U.S.
}

\section{Citation}

Cheng, Beiting, Suraj Srinivasan, and Gwen Yu. "Securities Litigation Risk for Foreign Companies Listed in the U.S." Harvard Business School Working Paper, No. 13-036, October 2012.

\section{Permanent link}

http://nrs.harvard.edu/urn-3:HUL.InstRepos:10212559

\section{Terms of Use}

This article was downloaded from Harvard University's DASH repository, and is made available under the terms and conditions applicable to Open Access Policy Articles, as set forth at http:// nrs.harvard.edu/urn-3:HUL.InstRepos:dash.current.terms-of-use\#OAP

\section{Share Your Story}

The Harvard community has made this article openly available.

Please share how this access benefits you. Submit a story.

\section{Accessibility}


H A R VAR D

\section{Securities Litigation Risk for Foreign Companies Listed in the U.S.}

Beiting Cheng

Suraj Srinivasan

Gwen Yu

\section{Working Paper}

13-036

October 19, 2012 


\title{
Securities Litigation Risk for Foreign Companies Listed in the U.S.
}

\author{
Beiting Cheng \\ becheng@hbs.edu \\ Suraj Srinivasan \\ ssrinivasan@hbs.edu \\ Gwen $\mathrm{Yu}$ \\ gyu@hbs.edu
}

October 2012

\begin{abstract}
We study securities litigation risk faced by foreign firms listed on U.S. exchanges. We find that U.S. listed foreign companies experience securities class action lawsuits at about half the rate as do U.S. firms with similar levels of ex ante litigation risk. The lower rate appears to be driven partly by higher transaction costs in uncovering and pursuing litigation against foreign firms. However, once a lawsuit triggering event like an accounting restatement, missing management guidance, or a sharp stock price decline occurs, there is no difference in the litigation rates between a foreign and comparable U.S. firm. This suggests that effective enforcement of securities laws is constrained by transaction costs, and the availability of high quality information that reveals potential misconduct is an important determinant of a well-functioning litigation market for foreign firms listed in the U.S.
\end{abstract}




\section{Introduction}

We examine the litigation risk from securities class action lawsuits for foreign companies listed in the United States. In the U.S., securities class action litigation provides investors with a mechanism to hold companies and managers accountable for violations of securities laws. This, among other reasons, is why foreign companies listing in the U.S. are expected to exhibit better governance outcomes since they bond themselves to the superior monitoring regime (Coffee 1999, 2002; Stulz, 1999). While prior research recognizes the governance role of securities litigation, there is limited research on the extent of litigation risk faced by foreign companies listed in the U.S. We examine the actual incidence of securities litigation against U.S. listed foreign companies, how it compares to litigation risk for U.S. companies, and the mechanism driving securities litigation risk for foreign companies.

There are reasons to expect that foreign firms will have a greater litigation likelihood compared to U.S. companies. Foreign firms from countries with weak investor protection can suffer from greater managerial or controlling shareholder expropriation risk suggesting a higher level of litigation risk for such companies. Lang et al. (2006) find that accounting quality is lower for U.S. listed foreign firms compared to their domestic U.S. counterparts, which can result in a higher risk of securities litigation. If foreign firms continue to exhibit weak governance and poor reporting behavior after listing in the U.S., this can lead to more frequent securities lawsuits against foreign companies.

On the other hand, litigation outcomes can also be less likely for foreign companies relative to U.S. ones. Plaintiff investors and attorneys often rely on information from external and internal company sources to provide evidence of the defendant's intent to deceive. For foreign firms, there can be less information available to investors for establishing the firm's intent relative 
to information for U.S. firms. For example, managers of cross-listed firms are subject to fewer insider trading disclosure requirements, thus depriving plaintiffs of information about a possible profit motive that can improve the prospects of a lawsuit. ${ }^{1}$ Srinivasan et al. (2012) show that the rate of restatements is lower for U.S. listed foreign firms compared to U.S. firms. Irregularities in financial statements are an important driver of class action lawsuits (Hennes et al. 2008) and the reluctance to admit misstatements can make it harder for plaintiffs to sue foreign firms. If there is insufficient information to trigger a lawsuit, the mapping of litigation risk to actual lawsuits might weaken for foreign firms leading to less frequent lawsuits relative to domestic U.S. firms.

Another factor affecting litigation rate is greater transaction costs for lawsuits against foreign firms than for U.S. firms. Managers of foreign firms likely reside in their home jurisdictions, increasing the costs of legal procedures such as depositions and discovery. Legal steps such as collecting evidence of misconduct and identifying a confidential witness are more challenging especially in countries where the litigation system is less developed (Kaufman and Wunderlich, 2011; Mark, 2011). Such additional costs can result in a higher bar for plaintiffs to pursue litigation against foreign firms relative to U.S. firms.

We examine all securities class action lawsuits filed for violation of Section 10b-5 or Section 11 of the Securities Acts against foreign companies listed in the U.S. using the Institutional Shareholder Services (ISS) Securities Class Action Clearinghouse database. For the period from 1996 to 2010, there are a total of 3,672 securities class action lawsuits filed which reduces to 2,132 after screening out cases that don't implicate companies (such as IPO allocation and analyst conflict of interest cases against investment banks) and those with missing data in

\footnotetext{
${ }^{1}$ The Exchange Act Rule 3a12-3(b) exempts foreign private issuers from filing periodic insider stock trading reports.
} 
CRSP and Compustat required for our multivariate tests. Of the 2,132 lawsuits, 178 cases are lawsuits against foreign firms from 59 countries.

To benchmark the litigation rate of foreign firms we create a propensity score based matched sample of U.S. firms that have similar risk of getting sued as the foreign sample based on the litigation risk model in Kim and Skinner (2012). The litigation rate for foreign firms is $2.16 \%$ (178 lawsuits in 8,243 foreign firm-years) compared to the $3.76 \%$ litigation rate $(310$ out of 8,243$)$ for domestic U.S. firms with similar ex-ante litigation risk. This lower rate holds in our multivariate tests after controlling for various factors known to be associated with litigation risk. In economic terms, this implies that foreign firms listed in U.S. are only half as likely to have a class action lawsuit as comparable U.S. firms, after controlling for ex ante litigation risk. ${ }^{2}$

We distinguish between the drivers of ex ante litigation risk and events that increase the likelihood of a lawsuit for a given level of litigation risk. For example, high growth firms are inherently subject to higher litigation risk due to their business risk. However, the incidence of actual litigation can differ depending on whether a trigger event occurs that allows investors to allege wrongdoing. We examine the impact of trigger events on foreign versus U.S. firms using three events which are most oft-cited causes of class action lawsuits: announcement of accounting restatements (Hennes et al., 2008), earnings announcement that misses management guidance (Matsumoto 2002), and a large drop in stock price (Jones and Weingram, 1996).

We confirm that triggers matter for litigation - in firm-years with a material accounting restatement $15.85 \%$ of foreign firms are sued, compared to only $2.22 \%$ for firm-years with no material restatement. We find that foreign firms have fewer instances of all types of trigger events than the full sample and matched sample of U.S. firms, providing one potential reason for fewer

\footnotetext{
${ }^{2}$ This calculation is based on the odds ratio of the estimated logit model. According to the first columns in Table 5, the odds ratio is calculated as $\exp ^{\beta 1}\left(=\exp ^{-0.59}=0.55\right.$ ), suggesting that the odds of a foreign firm versus a U.S. firm being sued is 0.55 .
} 
lawsuits against foreign firms. However, the difference in litigation rates between U.S. and foreign firms is significantly reduced once a trigger event occurs. While our multivariate results suggest that foreign firms are about half as likely to be sued as U.S. firms, a material restatement reverses the difference. Foreign firms with a material restatement are 2.18 times more likely to be sued than U.S. firms that report a material restatement. ${ }^{3}$ Similarly, foreign firm-years that failed to meet their management guidance are 1.14 times more likely to be sued than U.S. firms that missed their management guidance. Finally, in years with a large price drop, the difference in the litigation rate between U.S. and foreign firms is reduced with foreign firms being 1.26 times less likely to be sued than U.S. firms. This suggests that the availability of high quality triggers that reveals potential misconduct is important for a well-functioning litigation market.

Finally, we examine the role of transaction costs in the observed lower litigation rate for foreign firms. We use three transaction cost proxies: geographic distance from U.S., judicial efficiency in the home country, and the frequency of U.S. acquisitions in the home country. We find that foreign firms with higher transaction costs experience a lower incidence of lawsuits. Firms in countries in the upper quartile of geographic distance from the U.S. are 1.31 times less likely to be sued than in countries in the lower quartile of geographic distance, and those in countries in the lower quartile judicial efficiency score (or U.S. acquisitions) are 2.04 (1.21) times less likely to be sued than in countries with the upper quartile judicial efficiency score (U.S. acquisitions), after controlling for ex ante litigation risk. The lower frequency of lawsuits against foreign firms with greater transaction costs suggests the existence of additional costs in suing foreign firms. ${ }^{4}$ We find no evidence that trigger events can mitigate the effect of transaction costs

\footnotetext{
${ }^{3}$ See Table 6 column (1). As in footnote 2 , the odds ratio is calculated as $\exp ^{((a)+(b))}\left(=\exp ^{0.78}=2.18\right)$.

${ }^{4}$ The lower litigation rate of foreign cross listed firms (relative to U.S. firms) may suggest that foreign firms face only limited level of monitoring from private securities regulation. However, this rate is still higher than the litigation rate in the home country. In untabulated results, we find that the frequency of lawsuits against cross listed firms in the U.S.
} 
which continue to be an important driver of the lower litigation rate, even for firms that experience trigger events.

Our study is one of two contemporaneous papers of which we are aware that examine litigation against U.S. listed foreign firms. Gande and Miller (2012) examine a sample similar to ours, except that their sample period ends in 2008. They present univariate evidence, akin to ours, on the extent of litigation against foreign firms and conclude that foreign firms are subject to U.S. securities lawsuits in contrast to the limited extent of enforcement actions by the Securities and Exchange Commission (SEC), as documented in Siegel (2005). Unlike our study, they do not evaluate the rates of litigation against foreign firms in comparison to matched U.S. firms with similar ex ante litigation risk. Similarly, they provide descriptive evidence about settlements for foreign firms, however, with no comparison to a U.S. firm benchmark. Finally, Gande and Miller (2012) examine market reaction to the announcement of lawsuits against foreign firms and find a 6 percent drop in share price resulting in a $\$ 73$ billion loss in market value. They conclude that the market punishes the sued firms, which they interpret as a direct result of the litigation. They do not discuss whether the drop in stock price results from the underlying troubles that prompted the lawsuit or if it is an effect of the lawsuit itself. Our paper also differs from Gande and Miller (2012) as they do not examine litigation triggers or transaction costs.

We make some important contributions to the literature. First, this is one of the first papers to examine the extent of securities class action litigation against foreign firms listed in the U.S. Our evidence shows that significant litigation risk does exist for foreign issuers, but at rates that are considerably lower than for U.S. companies. We identify transaction costs and the lower rate of trigger events as potential factors in the lower litigation rates. However, the U.S. plaintiffs' bar

(2.3\%) is higher than the litigation frequency in the home country in the absence of cross listing $(0.8 \%)$ (See section 3.2). So, despite the lower litigation rate in the U.S., foreign firms are subject to greater enforcement of securities laws in the U.S. than in their home countries. 
is as responsive to informational triggers, such as accounting restatements and missing management earnings guidance, for foreign firms as it is for U.S. firms. Our findings relate to the effectiveness of U.S. private enforcement of foreign listed firms. In particular, we identify factors that could either limit (e.g., transaction costs) or facilitate (i.e., quality of triggers) the effectiveness of such enforcement. Hence, our study presents a more nuanced view of the institutional requirements for bonding than previously discussed in the literature.

Second, we contribute to the literature on litigation risk for companies. Research on predicting litigation risk focuses on U.S. companies (e.g., DuCharme et al., 2004; Field, Lowry, and Shu, 2005; Kim and Skinner, 2012) and does not examine foreign companies listed in U.S. Our study fills that gap and provides a litigation risk model for foreign companies listed in the U.S. that future researchers can use. The lower litigation rate for foreign firms has implications for the corrective corporate governance role of securities litigation. Litigation risk has been shown to exert a disciplinary influence on corporate practices relating to executive compensation, executive and board turnover, corporate investment, and voluntary disclosure (Lowry and Shu, 2002; Field et al., 2005; Ferris et al., 2007; Hanley and Hoberg, 2012; McTier and Wald, 2011; Rogers and Van Buskirk 2009; Skinner 1994 and 1997). The finding of lower litigation risk for foreign firms implies that, relative to U.S. firms, foreign firms will face less frequent pressure to improve disclosure quality and corporate governance or make other corrective actions following a lawsuit.

The rest of the paper proceeds as follows. In section 2, we discuss prior literature and develop our hypotheses. Section 3 describes the data and present descriptive statistics. In section 4, we present the multivariate evidence and conclude in section 5. 


\section{Prior literature, institutional details, and hypothesis development}

Coffee (1999) and Stulz (1999) advance the "legal bonding” hypothesis under which, by listing in the U.S., foreign firms subject themselves to U.S. legal institutions which improves their corporate governance. The effectiveness of legal bonding depends on the ability of the SEC and the plaintiffs' bar to punish violations of securities laws. Siegel (2005) finds that the SEC had not punished material violations by foreign firms and managers with meaningful sanctions and concludes that SEC actions offer no support for the validity of legal bonding. Coffee (2002), responding to Siegel's findings, suggests that even if the SEC was not effective at pursuing enforcement actions, the U.S. plaintiffs' bar could still be effective at disciplining foreign managers. However, research evidence on the extent of litigation risk for U.S. listed foreign firms is quite limited. ${ }^{5}$

Two recent developments make our research timely and relevant from a policy perspective. In June 2010, the U.S. Supreme court's ruling in the case of Morrison v. National Australia Bank substantially limited the extraterritorial reach of U.S. securities law for foreign firms. The ruling held that the reach of Securities Exchange Act Rule 10 (b) does not extend to shareholders who made their purchases outside of the U.S. For cross-listed firms, the ruling will limit eligible investors that can participate in a class action to only investors that purchased their shares in the U.S. exchanges thus limiting the extent of damages collected by investors. Thus, the Morrison case could have the effect of reducing the litigation risk of foreign firms listed in the U.S. ${ }^{6}$ In response and to partly undo the effect of the ruling, the U.S. Congress under the Dodd-Frank Act,

\footnotetext{
${ }^{5}$ To our knowledge, there has been no systematic empirical study of class action litigation against foreign firms except Gande and Miller (2012), which we discussed in the previous section.

${ }^{6}$ Licht et al. (2011) examine the market reaction following Morrison and find no negative stock price reaction for U.S. listed foreign firms. Gagnon and Karolyi (2011) compare the U.S. market reaction to that of the home market share prices and find that the price deviation widened by 37 basis points following this ruling. The authors interpret the findings in favor of the bonding hypothesis. Since the ruling had a large impact on foreign firms' exposure to litigation risk, we limit our sample period to the pre-Morrison period.
} 
provided the Department of Justice and the SEC authority to pursue transnational securities fraud even if they involved only foreign investors. Congress also directed the SEC to conduct a study of how the Congress could extend the scope of private litigation to include conduct occurring outside the U.S. and involving only foreign investors (SEC 2012). Policy responses to these developments should consider the extent and the sources of frictions in litigation against foreign companies which is the focus of our study.

We use the litigation risk model in Kim and Skinner (2012) to assess if foreign firms are more or less likely to be sued than comparable U.S. firms. They distinguish ex ante litigation risk, which are characteristics that make a firm more likely to be susceptible to litigation, from ex post litigation triggers, i.e., events that reveal potential wrongdoing such as large price drops. Following Kim and Skinner (2012), we identify a sample of U.S. firms that have an ex ante litigation risk similar to the foreign firms listed in the U.S. We consider the litigation rates for the U.S. sample as the benchmark rate and compare the realized litigation rate of the foreign sample to this benchmark. If the U.S. private enforcement were equally effective for both U.S. and foreign firms, we expect no difference in the litigation rate of both firms. Our first hypothesis stated in the null form is the following:

H1: Holding constant ex ante litigation risk, there is no difference in the litigation rate between U.S. listed foreign firms and U.S. firms.

Next, we identify factors that could facilitate the effectiveness of the private enforcement against foreign firms listed in the U.S. Prior literature finds that the availability of information triggers that allow plaintiffs to better uncover potential misconduct is an important determinant of an effective enforcement of private litigation. Siegel (2005) discusses the institutional obstacles private plaintiffs face in the U.S. and highlights the high informational burden on the plaintiffs as a major barrier to file a securities lawsuit. For example, plaintiffs need to produce 'specific' 
evidence that lead to strong inferences that the defendants acted 'willfully." ${ }^{7}$ The high standards of proof contained in the Private Securities Litigation Reform Act in 1995 have been a reason for dismissal of the majority of lawsuits. While these standards apply equally to U.S. and foreign firms, any lack of information for foreign firms adds an element of difficulty in pursuing foreign defendants as opposed to U.S. ones. ${ }^{8,910}$ Thus, we predict that, the difference in the litigation rates between foreign and U.S. firms reduces with the existence of a triggering event that provide investors information to verify the misconduct, holding constant ex ante litigation risk.

H2: The difference in the litigation rate of foreign firms and the U.S. firms (with similar ex ante litigation risk) will reduce once there is a trigger event that makes it easier for investors to identify and initiate a class action lawsuit.

We examine three trigger events from prior literature that may provide information about the underlying misconduct of the firm; 1) accounting restatements, 2) failure to meet management forecasts, and 3) sharp drops in stock price. Prior research has found that restatements are an important determinant of litigation (Palmrose and Scholz, 2004; Hennes et al., 2008). Material restatements can be an indicator of past misconduct and allow the plaintiffs to make specific complaints ("particularity") and allege "scienter" if officers and directors sold shares during the

\footnotetext{
${ }^{7}$ Plaintiffs much first show that the defendants acted with "scienter" i.e., they willingly or recklessly ignored the illegality associated with the actions. Second, the plaintiffs have to make their allegations "with particularity" i.e., evidence that is specific.

${ }^{8}$ One difference noted earlier is that foreign firms are not required to provide periodic insider trading reports thus depriving plaintiffs from alleging private benefits in case company officers sold shares in the class period. Since unusual or large insider selling is considered by Courts as indicative of scienter, lawsuits against U.S. firms typically mention insider selling in their allegations (Johnson et al., 2007, Rogers 2008)

${ }^{9}$ Srinivasan et al (2012) find that U.S. listed foreign firms restate at a smaller rate than comparable U.S. firms, even if the foreign firms have weaker accounting quality and when they have internal control weaknesses. This implies that the availability of quality restatement triggers that reveal the firms' misconduct may vary for U.S. and foreign firms.

${ }^{10}$ A leading plaintiff attorney, William Lerach suggests that law firms use a number of information sources to investigate potential lawsuits. These include SEC filings, financial and trade publications, on-line data bases, reports of analysts and rating agencies, former employees, customers and experts on that firm or its industry (Lerach 1988, Jones and Weingram 1996)
} 
misstated period. We expect that once a restatement is announced, there will be little difference in the litigation rate between foreign and U.S. firms. In our empirical tests, we examine whether the difference in the litigation rates between a foreign and U.S. firm with similar ex ante litigation risk is reduced once a restatement is announced.

Our second trigger event is the firms' failure to meet management forecasts. Skinner (1994) finds that firms issue more conservative management forecasts to avoid future litigation, consistent with the notion that providing management forecasts deters litigation. Francis et al. (1994), on the other hand, find more frequent earnings forecasts by firms in high litigation risk industries, contradicting the notion that providing management forecast deters future litigations. More recently, papers argue that the properties of the management forecasts determine whether they increase or deter future litigation. For example, Rogers, Van Buskirk and Zechman (2011) find that when management disclosures are unusually optimistic in their tone, these firms are more likely to be sued relative to other similar firms that provide management guidance. Since our interest is in whether management forecasts provide investors the information that will directly affect the ease to which investors can identify and initiate a lawsuit, we focus on quantitative information events rather other qualitative (e.g., optimism of the manager) properties of the management disclosure. In our empirical tests, we consider the firms' failure to meet management forecasts as one trigger event that allows investors to identify potential litigation. ${ }^{11}$

\footnotetext{
${ }^{11}$ Firms also respond to litigation by changing corporate behavior after they are sued. Rogers and Van Buskirk (2009) find that firms reduce the extent of disclosure post litigation which can help limit exposure to litigation. Dai et al., (2009) find that CEO pay in U.S. firms corrects to reduce excess compensation practices after securities lawsuits. Executives and board of directors face disciplinary turnover in the sued firm and reputational penalties in the labor market when their companies experience securities litigation (Fich and Shivdasani, 2008; Niehaus and Roth, 1999). To the extent litigation risk varies for foreign companies, the response is likely to differ as well. This implies that the behavior of U.S. listed foreign firms is likely to be different from U.S. firms to the extent corporate actions are driven by litigation risk.
} 
The final trigger event we examine is large drop in the firm’s stock price. Large declines in stock price are considered an important factor in screens that plaintiff attorneys adopt to identify potential litigation targets (Jones and Weingram 1996). A significant stock price decline indicates new negative information. To the extent the shareholder value loss is caused by managerial actions, such as a failed product or lack of prior disclosure of an unsuccessful project, it provides a potential cause for shareholders to file a lawsuit.

Next, we consider factors that may limit the effectiveness of U.S. private litigation. Prior research that suggests that U.S. litigation affects cross-listing decisions does not consider any variation in the litigation risk based on the country of origin of the firms (e.g., Seetharaman et al 2002; Choi et al., 2009). However, given the requirements of the litigation process, it is likely that the plaintiffs face differing levels of hurdles in pursuing litigation based on the country of origin of the defendant. We posit that one driver of litigation rates across companies is the transaction cost associated with pursuing the litigation. Such cost can involve the direct cost of deposing the defendants in the home country, as well as collecting evidence and identifying confidential witnesses and possible whistle blowers, much of which will need to be done in the foreign jurisdiction; there is also the indirect effect of the ease with which U.S. based attorneys can conduct their investigation in the foreign country.

H3: Holding constant ex ante litigation risk, the litigation rate of foreign firms will increase with transaction costs associated with pursuing the lawsuit.

We advance three parsimonious measures of country level transaction costs. ${ }^{12}$ The first measure is the geographic distance between the home country and the U.S. Geographic distance is

\footnotetext{
${ }^{12}$ The choice of the transaction cost variables, while based on the law and economics literature, is exploratory and captures the direct and indirect costs for plaintiffs to pursue a lawsuit. They are also based on our interviews with various plaintiff attorneys involved in pursuing litigation against U.S. listed foreign companies.
} 
used in prior research to measure the cost of information acquisition and monitoring (Portes and Rey, 2005; Mian 2006). Our interviews with plaintiff attorneys indicate that this is a relevant measure of the costs of conducting investigations and depositions which are likely to be higher in countries farther from the U.S. Next, we use the efficiency of the legal system in the home country as another measure of transaction cost. Countries with higher domestic judicial efficiency are likely to have a better legal infrastructure that make it easier for U.S. based law firms to find local partners. Moreover, we understand from our interviews that plaintiffs often look for whistle blowers and local sources to serve as confidential witnesses or to provide or validate information. Countries with a tradition of judicial efficiency are more likely to provide conditions that motivate individuals to act as witnesses or whistle blowers. Finally, we use the frequency of acquisitions conducted by U.S. companies in the home country as an inverse measure of transaction costs. Acquisition transactions are preceded by legal and financial reporting due diligence and contracts to safe guard interests of the acquirer. Countries where U.S. acquirers have conducted past transactions are likely to be ones where there exists a domestic infrastructure for legal and contractual activities. Therefore, we consider prior rates of acquisitions as indicative of the ease with which U.S. lawyers can conduct legal business in different countries.

In our empirical tests, we examine whether litigation rates within foreign firms systematically differ by the extent of transaction cost proxies. In addition, we examine whether conditioning on trigger events can mute the effect of transaction costs or whether these costs continue to be a deterrent to litigation, even for firms that experience trigger events.

\section{Sample and descriptive statistics}

\subsection{Sample construction}


Our sample consists of all foreign firms listed on major U.S. exchanges from 1996 to 2010. We classify firms as foreign if they are either headquartered or incorporated in a foreign country. Home country identification is based on the country where the firm is headquartered using the variable LOC from Compustat. For firms incorporated in a foreign country but headquartered in the U.S, we use the country of incorporation as the firm's home country. ${ }^{13,14}$ Following Lang et al. (2003), we exclude Canadian firms because the similarity in the legal systems of Canada and the U.S can make it more likely for investors to file a class action lawsuit in a Canadian court. ${ }^{15}$ We drop firm-years that lack the financial data in Compustat and CRSP required for calculating the ex ante litigation risk. Share prices and returns for the domestic and foreign firm samples are for the securities listed in the U.S. market. These selection criteria provide us with a sample of 8,243 foreign firm-years from 59 countries. Table 1 shows the sample selection process. The litigation sample is obtained from the ISS Securities Class Action Services database, which includes all securities class action lawsuits filed against public firms in the U.S. We exclude IPO cases, analyst cases and cases filed against specific securities products issued by investment banks like mortgage backed securities. ${ }^{16}$ After eliminating cases with missing information in CRSP and Compustat, our final litigation sample consists of 2,132 class actions: 178 cases against foreign companies and 1,954 against U.S. companies. ${ }^{17}$

\footnotetext{
${ }^{13}$ The one exception to this rule is firms incorporated in offshore centers (and headquartered in the U.S.). Since incorporation in offshore centers is often for tax reasons, one can argue that the nationalities of such firms are better represented from the headquartered country. We therefore exclude such from our foreign firm sample.

${ }^{14}$ Firms with foreign headquarters but with U.S. incorporation are typically those that acquire a U.S. firm (reverse merge) to bypass the stringent listing requirements in the U.S. We include these firms in our foreign sample. In sensitivity analysis, we conduct robustness tests after excluding such firms from the foreign sample (See Table 9).

${ }^{15}$ The difference in the frequency of litigation cases for foreign and U.S firms increases even more when we include Canadian firms.

${ }^{16}$ Analyst cases are those where the SEC files a complaint based on a conflict of interest with the research analyst and the plaintiff firm. These arise from alleged wrongdoings on part of the sell side analyst during the firm's IPO.

${ }^{17}$ This number is reduced to 150 cases in later analysis (e.g., Table 8), where we examine the resolutions and outcomes of the lawsuits. We exclude 21 active cases and 23 cases that do not have a class period, class period price information, or year-end sales information.
} 
We construct our sample of U.S. firm-years by identifying firm-year observations with a level of litigation risk similar to that of the foreign firm. For a U.S. firm-year to be considered a match with a foreign firm-year, it must be in the same year and have the same two-digit SIC code. We then choose the U.S. firm-year with the closest litigation risk score to the foreign firmyear. In addition, we directly control for a wide range of variables that capture ex ante litigation risk in the multivariate analysis. We include prior year firm size (log total assets), sales growth, and an indicator for high litigation industry based on membership in the biotechnology, computers, electronic, and retail industries following Francis, Philbrick, and Schipper (1994) (FPS industry hereafter). Following Kim and Skinner (2012), we use prior year return, return skewness, return volatility, and sales turnover as proxies that make firms more vulnerable to litigation. ${ }^{18}$ Note that all variables are measured at the fiscal year prior to the case filing date. This time lag is important because the underlying litigation risk on which we attempt to match is the ex ante litigation risk before any triggering events occur (Kim and Skinner, 2012). Triggering events, such as a sudden decline in current stock prices, a low EPS unforeseen by the management, or an announcement of accounting irregularities, are a catalyst for investors to file a class action lawsuit. Therefore, in the main analysis we examine the explanatory power of different trigger events after controlling for the ex-ante litigation risk.

Table 2 shows the descriptive statistics of the foreign (column 1) and U.S. matched sample (column 2) firms. We also include descriptive statistics for all U.S. firms (column 3) for comparison purposes. Not surprisingly, the litigation risk score of the foreign firms (column 2) is more similar to that of the matched U.S. firms than to the universe U.S. firms. The difference in

\footnotetext{
${ }^{18}$ Operationally, we estimate the litigation risk model based on the U.S. firms and recover the coefficients to construct the litigation risk score of the foreign sample. We do not allow the litigation risk model to vary across foreign and domestic firms because this will result in a similar litigation probability of foreign and domestic firms by construction.
} 
the firm characteristics between the larger U.S. universe and the matched U.S. sample reflects the importance of considering a benchmark for foreign firms with comparable litigation risk. ${ }^{19}$

Table 2 also presents the descriptive statistics of the litigation triggers across foreign and U.S. firms. We use 1) accounting restatements (available from year 2000 onwards), 2) missing earnings guidance, and 3) large drop in equity prices as triggers of lawsuits. Accounting restatements and missing management earnings guidance trigger lawsuits because it allows plaintiffs to claim that managers misrepresented the financials, providing them with a justification to sue the firm (Palmrose and Scholz, 2004; Skinner 1994). Table 2 shows that 1\% of the foreign firm-year sample reports at least one restatement, compared to the $4 \%$ in the matched U.S. sample - the lower rate for foreign firms is consistent with prior findings in Srinivasan et al. (2012). We include only material restatements, and exclude restatements due to minor errors and omissions by limiting restatements to those that are announced prominently with a separate filing such as an $8-\mathrm{K}, 6-\mathrm{K}$, or press release. ${ }^{20}$

The second trigger event is the failure to meet management guidance which can lead to a lawsuit when managers provides overly optimistic view of the firm or fail to disclosure bad news on a timely basis. We use management guidance from Thomson First Call's Company Issued Guidance (CIG) database. ${ }^{21}$ Empirically, we follow the classification in Anilowski et al. (2005) and categorize management guidance into five different types: point, range, maximum, minimum, or qualitative guidance. A firm is considered to have missed its management guidance when the

\footnotetext{
${ }^{19}$ Even after using a matched sample, we find that the foreign firms and the matched U.S. firms continue to have different firm characteristics. Foreign firms are larger and have a lower sales growth rate than the matched U.S. firms at the mean and median levels. Therefore, in our regression analysis we directly control for size and sales.

${ }^{20}$ The SEC introduced the Final Rule: Additional Form 8-K Disclosure Requirements and Acceleration of Filing Date (SEC 2004), which requires all material misstatements to be filed in the separate form (6-k, 8-k or a press release) and not within the regular periodic filings (10-k, 10-Q, or 20-f).

${ }^{21}$ Chuck et al. (2012) find systematic bias in the coverage of First call's CIG database by various firms characteristic and by different time periods. We employee a matched sample design and compare firms with similar characteristics within the same fiscal year.
} 
reported EPS is lower than the point forecast number, the mean of the range forecast, or the minimum forecast. We use reported EPS from Compustat using the basic EPS including extraordinary items. ${ }^{22}$ Foreign firms miss management guidance significantly less than U.S. firms (4\% versus $14 \%)$.

The third trigger event is the existence of a large drop in stock price. Large drop in security prices makes it easier for plaintiffs to establish loss causation - investors relied on the company’s information and suffered a loss (Jones and Weingram 1996). Empirically, we measure large price drops with an indicator variable that equals 1 if the company has at least one weekly return that drops by more than $30 \%$ in fiscal year. Table 2 shows that foreign firms have severe price drops (i.e., price drops greater than 30\%) far less frequently (9\%) relative to the matched U.S. firms (13\%).

\subsection{Litigation sample}

Table 3, Panel A presents the distribution of firm-year observations and litigation by the country of the firm's headquarters. 178 cases are filed against foreign firms, the top three countries being China, Israel, and the U.K. Firms from more than 20 countries have never had a securities lawsuit filed against them in the U.S. we present the frequency of the litigation relative to the total number of firm-years in each sub-sample. The litigation rate (column (3)) of $2.16 \%$ for foreign firm-years and $2.50 \%$ for the complete U.S. firm-year sample, suggests similar litigation rates. However, comparing the litigation rates to the U.S. matched sample shows a greater difference (2.16\% vs. 3.76\%) between the litigation frequency of the domestic and foreign firms. We find similar patterns when we compare the \% of firms (rather than firm-years) that face class action lawsuits in column (4). Panel A shows that $12.16 \%$ of the foreign firms in our sample

\footnotetext{
${ }^{22}$ In untabulated analysis, we also use basic EPS excluding extraordinary items and diluted EPS. All four measures yield qualitatively same results.
} 
face a class action lawsuit which is lower than the $23.37 \%$ (14.43\%) observed for the matched U.S. firm (the complete U.S. firm) sample. The difference in the litigation rates highlights the importance of considering a proper benchmark sample when evaluating the frequency of litigation for foreign firms. Thus, in our subsequent analysis we focus only on the comparison with the matched U.S. sample.

Table 3, Panel B shows the frequency in litigation rates by filing year. The rate of lawsuit filings varies with the economic cycle. ${ }^{23}$ The litigation rates show a record high in year 2001 for U.S firms (5.89\%) following the dot com bubble; there is another sharp increase following the mortgage banking crisis in 2010 for both U.S. and foreign firms. Our empirical tests control for the time varying nature of litigation risk using year fixed effects.

Table 4 Panel A provides a univariate comparison of the litigation rate for foreign and matched U.S. firms show that foreign firms have lower litigation rate (2.16\%) relative to the U.S. firms with similar litigation risk (3.76\%). While the descriptive evidence is interesting, we note that the foreign listed firms and U.S. firms have different firm characteristics that subject them to different levels of litigation risk. Therefore, in addition to controlling for such ex-ante litigation risk factors, we use a matched U.S. firm sample to control for the firm characteristics that affect the ex-ante litigation risk, as discussed later.

Table 4, Panel B presents descriptive statistics relating to the lawsuit characteristics for lawsuits with financial data available in our regression model. ${ }^{24}$ For our tests of litigation outcomes - dismissal likelihood, settlement amount, and settlement speed - we create a second matched U.S. sample using only the sued firms. The matched U.S. litigation sample is selected by

\footnotetext{
${ }^{23}$ The Securities Exchange Act of 1934 requires that lawsuits be filed within two years after the discovery of the fact of the violation or within five years after the violation (NERA 2011).

${ }^{24}$ We exclude 21 active cases and 31 cases missing a class period, a class period price drop, market value or a yearend's sales number. This reduces the litigation sample from 178 (Table 2) to 126 cases.
} 
matching on firm size (i.e., log of beginning of the year market value) in the same FPS industry and fiscal year. In untabulated analysis, we also match on additional variables that capture lawsuit characteristics (e.g., the log value of the class period, level of class period price drop, and a propensity score matching on the dismissal score based on the dismissal model), which all generate qualitatively similar results. This ensures that the difference in settlement outcomes across domestic and foreign firms is not driven by differences between the lawsuit characteristics in the two samples.

Using the matched sample, we compare whether lawsuits result in different outcomes for foreign firms. Out of the 126 lawsuits against foreign firms, 57 are dismissed, and 68 are settled. The portion of cases that are settled is slightly lower for the foreign cases (68\%) than the matched U.S. cases $(73 \%)$ in the univariate test $(p-$ value $=0.12)$. The foreign and the U.S. matched sample show no statistically significant difference in the settlement amounts, but the level is higher for the foreign cases (\$87.33 million) than the matched cases ( $\$ 22.40$ million). The average time to settle at 1,311 days for the foreign firms are statistically higher than 1,100 days for the U.S. matched sample. Overall, comparing the characteristics of lawsuits in Panel B, we find that the lawsuits have similar outcomes (e.g., dismissal and settlement amounts) once they have been filed.

\section{Empirical results}

\subsection{Frequency of litigation for foreign firms}

In Table 5, we compare the litigation rates for foreign firms relative to the U.S. matched firm sample. We use the following multivariate litigation model to examine foreign firms' litigation likelihood relative to the U.S. matched sample. In addition to controlling for firm characteristics that affect ex ante litigation risk (Kim and Skinner, 2012), we include an indicator variable to 
compare the foreign firms to the U.S. firms selected based on the matching procedure described in section 3.1.

$$
\text { Litigation }_{i, t}=\beta_{0}+\beta_{1} \text { Foreign Indicator }_{i}+\beta_{3-10} \text { Firm_Controls }_{i, t}+\text { Year FE }+\varepsilon_{i, t} .
$$

The dependent variable Litigation $_{i, t}$ equals 1 if firm $i$ has a lawsuit filed in fiscal year $t$, zero otherwise. Foreign Indicator $r_{c}$ is the primary variable of interest; it equals 1 for U.S. listed foreign firms, and zero otherwise.

We use a number of control variables that are hypothesized to affect the risk of litigation. Kim and Skinner (2012) argue that a parsimonious model that includes FPS industry, size, prior year sales growth, and prior year stock return metrics captures the predictability of litigation risk in the U.S. Finally, we include year fixed effects to account for the possibility of litigation filings clustering in certain time periods.

The first column of Table 5 presents estimates the logistic regression in equation (1). Model (1) shows the estimated coefficients using the pooled foreign and U.S. matched firm sample. The coefficient estimate on Foreign indicator is negative and statistically significant (coefficient = 0.59, p-value $<0.001$ ), suggesting that U.S. listed foreign firms are less likely to be sued relative to the matched U.S. sample. In economic terms, this implies that foreign cross-listed firms are 1.80 times less likely to have a class action lawsuit than the U.S. firms are, after controlling for the ex ante litigation risk. ${ }^{25,26}$ Consistent with Kim and Skinner (2012), we find that FPS industry

\footnotetext{
${ }^{25}$ This calculation is based on the odds ratio of the estimated logit model. According to the first columns in Table 5, the odds ratio is calculated as $\exp ^{\beta 1}\left(=\exp ^{-0.59}=0.55\right)$, suggesting that the odds of a foreign firm versus a U.S. firm being sued is 0.55 .

${ }^{26}$ Because the unit of observations is litigation-years for each firm, it is possible that our analysis includes repeated observations if a firm has multiple lawsuits filed during a year. The repeated firm-observations might raise concerns of inflated statistical significance that cannot be completely adjusted by clustering standards errors at the firm level. In untabulated analysis, we estimate our test after including an indicator variable for firm-years that have already faced a class action lawsuit in the current year. We find that this indicator variable is positive and significant, and our results remain robust to inclusion of this control. Also, we re-estimate the regression after dropping all litigations that occurred after the lawsuits for a given firm-year. Our results remain robust to dropping the 90 lawsuits.
} 
identification, firm size, sales growth, prior year returns, prior year return skewness, prior year volatility, and prior year trading volume are all significant determinants of litigation. Litigation risk increases with being in an FPS industry, prior year size, sales growth, return volatility, and trading volume. The negative sign on the prior year return suggests that for foreign firms (and the matched U.S firms) lower stock performance is associated with higher litigation risk. ${ }^{27}$

\subsection{Effect of transaction costs on litigation risk for foreign firms}

We next examine whether various transaction cost variables discussed earlier can explain the difference in the litigation rate within the foreign sample. While the choice of the transaction cost variables is exploratory, our motivation is to identify the drivers of the additional cost of lawsuits against foreign firms. We therefore investigate a number of measures employed in the literature using the following prediction model:

$$
\text { Litigation }_{i, t}=\beta_{0}+\beta_{2} \text { Transaction costs }_{i, t}+\beta_{3-10} \text { Firm_Controls }_{i, t}+\text { Year FE }+\varepsilon_{i, t} .
$$

The dependent variable Litigation $_{i, t}$ equals 1 if firm $i$ has a class action filed in fiscal year $t$, zero otherwise. The first transaction cost variable we examine is Geographic distance measured as the log of the shortest distance between the capital city of the home country of the foreign firms and New York using the great circle formula. Geographic distance is shown to account for much of the variation in the cross border flows of both real goods and financial assets (Mian 2006) and has been interpreted as a measure of information acquisition cost (Portes and Rey, 2005). In our context, information acquisition costs can involve the cost to obtain information that identifies whether a firm is an appropriate target for a lawsuit, as well as costs related to pursuing the class action e.g., collecting local information, finding witnesses, and conducting depositions. Therefore,

\footnotetext{
${ }^{27}$ One concern with the returns measure is that it might be capturing downward stock price movements that trigger litigation. We deliberately avoid this possibility by including abnormal returns measured during the period prior to the year the lawsuit was filed. It captures the 12-month cumulative market-adjusted return ending in the fiscal year before the year in which the lawsuit was filed
} 
geographic proximity is indicative of the ease with which U.S. lawyers can gather information in different countries.

Next, we include the efficiency of the domestic legal environment (Judicial efficiency) as an inverse measure of transaction costs. The lawsuits against foreign firms often involve discovery related activities in places where the misconduct occurred. The home country's legal system will affect the ease with which investors and lawyers can conduct such activities, affecting the cost of class actions. For example, collecting evidence of misconduct in foreign countries will be directly affected by the attitude towards litigation in different countries. Empirically, we use the judicial efficiency index from International Country Risk (ICR) used in Jackson and Roe (2009). A higher judicial efficiency in the home country indicates the availability of legal and investigative resources in the home country that can lower transaction costs for a U.S. based plaintiff attorney.

Finally, we include the total number of cross-border acquisitions in each foreign country by U.S. acquirers (U.S. acquisitions) as an inverse measure of transaction cost. Cross-border acquisitions transactions are often preceded by legal due diligence to safe guard interests of both the acquirer. We consider prior rates of U.S. acquisitions in the foreign country as indicative of the ease with which U.S. lawyers can conduct business and other information gathering in different countries. The measure is calculated as the log value of total number of cross-border acquisitions in each foreign country by U.S. acquirers from 1990 to 2007.

Models (2) to (4) of Table 5 present the multivariate result of estimating the litigation model using the transaction cost variables. Model (2) shows that Geographic distance is estimated with a negative and statistically significant coefficient $(=-0.40$, $p$-value $=0.002)$, suggesting that firms in countries that are further away from the U.S. are less likely to have lawsuits filed against them. In economic terms, firms in countries in the upper quartile distance are 1.31 times less likely to be sued than those in countries in the lower quartile distance, after controlling for ex ante litigation 
risk factors. Model (3) shows the estimated results using Judicial efficiency as a measure of the inverse of transaction costs. ${ }^{28}$ We find a positive and statistically significant coefficient $(=0.26$, p-value=0.001), suggesting that foreign firms from countries with a more efficient judicial system are more likely to be sued. In Model (4), using U.S. acquisitions as the measure of transaction costs, we find that firms in countries with more frequent U.S. acquisitions are more likely (coefficient $=0.20$, p-value $=0.002$ ) to be sued. In economic terms, this suggests that firms in countries with frequency of U.S. acquisitions in the upper quartile are 1.21 times more likely to be sued than firms in countries with the frequency in the lower quartile, after controlling for ex ante litigation risk. The findings suggest that the lower litigation rate for foreign firms is due in part to the higher transaction costs of pursuing securities class action litigation against foreign firms listed in the U.S.

\subsection{Frequency of litigation against foreign firms conditional on trigger events}

We examine whether the existence of trigger events can reduce the difference in litigation rates between U.S. listed foreign firms and U.S. firms. As discussed in the introduction, we distinguish between ex ante litigation risk and events that are likely to increase the probability of a class action lawsuit. For example, growth firms in risky industries might inherently be subject to higher ex ante litigation risk. However, in the absence of certain events that actually trigger a lawsuit (e.g., an accounting restatement, an unexpected low earnings number or large price drop), investors can find it challenging to successfully establish malfeasance as the basis for the suit.

\footnotetext{
${ }^{28}$ The number of observations is reduced in both models 3 and 4 due to missing data on judicial efficiency for 21 countries and 18 countries on U.S. acquisitions.
} 
We compare the domestic and foreign firms that have similar ex ante litigation risk and examine the difference in the litigation rate between foreign and domestic firms conditional on having a trigger event using the following model:

$$
\begin{aligned}
& \text { Litigation }_{i, t}=\beta_{0}+\beta_{1} \text { Foreign indicator }_{i}+\beta_{2} \text { Trigger }_{i, t}+\beta_{3} \text { Foreign indicator }_{i} * \text { Trigger }_{i, t}+ \\
& \beta_{4-11} \text { Firm_Controls }_{i, t}+\text { Year FE }+\varepsilon_{i, t} \text {. }
\end{aligned}
$$

The dependent variable Litigation $_{i, t}$ equals 1 if firm $i$ has a lawsuit filed in fiscal year $t$, and zero otherwise. Foreign indicator ${ }_{c}$ equals 1 for foreign cross-listed firms, zero otherwise. Trigger $_{i, t}$ is an indicator variable that equals 1 for firm-years with observed trigger events as described in section 3.1, and zero otherwise. We use material restatements (available from 2000 onwards), missing management guidance and large price drops (the latter two both available throughout the sample period) as trigger events. The coefficient on the interaction term (Foreign indicator $_{i}$ * Trigger $_{i, t}$ ), $\beta_{3}$, is our main variable of interest, indicating the differential likelihood of litigation against foreign firms relative to U.S. firms conditional on having a trigger event.

Table 6, Panel A presents a univariate comparison of the percentage of firm-years with class action lawsuits for foreign companies and the matched U.S. sample conditional on the existence of a trigger. Panel A shows that firm-years with trigger events have a significantly higher likelihood of a lawsuit being filed relative to firm-years without a trigger for both domestic and foreign firms. For foreign firm-years that report a material restatement, $15.85 \%$ are sued, compared to the $2.22 \%$ litigation rate for firm-years with no restatements. Similarly, for U.S. firms, a restatement event increases the likelihood of litigation rates from $3.95 \%$ to $7.63 \%$. Using missing management guidance as the trigger event, we find that the litigation rate increases from $2 \%$ to $6.23 \%$ for the foreign firms sample and from $3.34 \%$ to $6.23 \%$ for the U.S matched firm sample. We find similar findings using large price drop (large price drop) as the trigger event. In the absence of a large price drop, we find statistically significant ( $p$ value $<0.001$ ) difference in 
the litigation rate of foreign firms (1.56\%) and U.S. firms (2.82\%). Once we condition on observing a large price drop, we find only weak statistical significance (p-value=0.10) in the difference between foreign and U.S. firms litigation rates.

In Panel B, Table 6, we examine the differential litigation risk conditional on litigation triggers for foreign and matched U.S. firms. Model (1) uses restatements as the trigger event. Material restatement is an indicator variable that takes a value of one if there is a material restatement announcement between the beginning of the fiscal year and the lawsuit filing date. ${ }^{29}$ Model (1) shows that the coefficient on the material restatement trigger is positive and significant (coefficient $=0.70, \mathrm{p}$-value=0.009), indicating that observing a restatement significantly increases the likelihood of lawsuit filings (Hennes et al. 2008). The coefficient on foreign indicator is significantly negative (coefficient $=-0.62$, $\mathrm{p}$-value $<0.001$ ), confirming the previous finding that foreign firms are less likely to be sued on average.

More importantly, the interaction term of material restatement trigger and foreign indicator is positive and statistically significant (coefficient $=1.40$, p-value $=0.007$ ), suggesting that the restatement frequency of foreign firms shows a higher litigation rate relative to U.S. firms, once we condition on the existence of a restatement. Interestingly, the estimated coefficients suggest that the frequency of foreign firm litigation is no longer statistically different from the litigation rate of U.S. firms, once we condition on a trigger event occurring $\left(\beta_{1}+\beta_{3}=0.78\right.$, $\mathrm{p}$-value=0.12). This suggests that the lower frequency of litigation for foreign firms is not because plaintiffs respond less significantly to litigation trigger events. The litigation rates show a greater sensitivity to such trigger events for foreign firms, once a trigger event has taken place.

\footnotetext{
${ }^{29}$ Material restatements are defined as restatements that satisfy the materiality threshold requirements of the SEC and are announced via either Form 8-K, Form 6-K, a press release which are vehicles for timely disclosures in contrast to less material ones that are disclosed in routine filings such as the $10-\mathrm{K}$ or $10-\mathrm{Q}$. The SEC requires firms to file a timely disclosure like an 8-K for restatements that exceed the materiality threshold (The Final Rule: Additional Form 8-K Disclosure Requirements and Acceleration of Filing Date, SEC 2004).
} 
Model (2) uses the Missing management guidance indicator as the litigation trigger - a variable that takes a value of one if the company's fiscal year end EPS in the prior year fails to meet the forecasts provided by the management, and zero otherwise. Model (3) shows that the coefficient on Missing management guidance is positive and statistically significant (coefficient $=$ 0.41 , p-value $<0.001$ ), indicating that missing a management guidance is a material event that leads to greater lawsuit filings. As in the restatement tests, we find that the frequency of foreign firm litigation is no longer statistically different from the litigation rate of U.S. firms, once we condition on a trigger event occurring $\left(\beta_{1}+\beta_{3}=0.13\right.$, $\mathrm{p}$-value $\left.=0.627\right)$.

Model (3) uses the Large price drop indicator as the litigation trigger - a variable that takes a value of one if the company has at least one weekly returns drop of more than $30 \%$ from the start of the fiscal year in which the lawsuit is filed to the lawsuit filing date, and zero otherwise. Model (3) shows that the coefficient on Large price drop is positive and statistically significant (coefficient $=1.88$, p-value $<0.001)$, indicating that a price drop is a material event that leads to greater lawsuit filings. The estimated coefficient suggests that firms with a sharp drop are 6.55 times more likely to have a lawsuit filed against them on average. ${ }^{30}$ For foreign firms, the odds of having a lawsuit filed increases by 10.49 times once a price drop is observed relative to foreign firms that do not have a stock price drop, ${ }^{31}$ and foreign firms are only 1.26 times less likely to be sued than U.S. firms after the trigger (compared to 2.01 less likely before). Overall, the results imply that conditioning on triggers, the litigation rate of foreign firms are comparable to or even greater than that of the U.S. firms. This indicates that the occurrence of trigger events is an important determinant of a well-functioning litigation market.

\footnotetext{
${ }^{30}$ The 6.55 figure is based on the odds ratio of the estimated logit model. The odds ratio is calculated as $\exp ^{\beta 1}$ (= $\left.\exp ^{1.88}\right)$.

${ }^{31}$ As in footnote 26, the odds ratio is calculated as $\exp ^{(1.88+0.47)}(=10.49)$.
} 
Finally, we examine the effect of various transaction costs on the litigation rates of firms conditional on trigger events. In particular, we examine whether the effect of transaction costs are mitigated after conditioning on a trigger event. We use the following model:

$$
\begin{array}{r}
\text { Litigation }_{i, t}=\beta_{0}+\beta_{1} \text { Transaction cost }_{i, t}+ \\
\beta_{2} \text { Trigger }_{i}+\beta_{3} \text { Transaction cost }_{i, t} * \text { Trigger }_{i, t}+ \\
\beta_{4-11} \text { Firm_Controls }_{i, t}+\text { Year FE }_{-} \varepsilon_{i, t} \text { (4) }
\end{array}
$$

The dependent variable Litigation $_{i, t}$ equals 1 if firm $i$ has a class action filed in that fiscal year $t$, and zero otherwise. The transaction cost variables are described in section 4.1. Trigger $_{i, t}$ is an indicator variable that equals 1 for firm-years with observed trigger outcomes, as described in section 3.1, and zero otherwise. The coefficient on the interaction term $\beta_{3}\left(\right.$ Trigger $_{i, t} *$ Transaction cost $t_{i}$ ) examines the changes in the effect of transaction costs once we condition on observing a trigger event.

Table 7, Panel A shows the estimated results using geographic distance as the transaction costs variable. Conditioning on material restatement triggers in Model (1), we find that the negative effect of the transaction costs remains significant (coefficient $=-0.33$, $\mathrm{p}$-value $=0.022$ ). The interaction term $\beta_{3}$ (Trigger ${ }_{i, t} *$ Transaction $_{\text {cost }}$ ) is positive but insignificant (coefficient $=$ 0.35 , $\mathrm{p}$-value $=0.57$ ), suggesting that the negative effect of transaction costs are not reduced after conditioning on observing a restatement event. Using alternative trigger events in Models (2) to (3), we find consistent results.

In Panel B, we use Judicial efficiency as the transaction cost variable. In Model (1), we condition on the restatement trigger and find that the effect of transaction costs remains significant (coefficient $=0.24$, p-value $=0.006$ ). We find no evidence of the effect of transaction costs reducing once we condition on observing a trigger event. That is, the interaction term $\beta_{3}$ $\left(\right.$ Trigger $_{i, t}{ }^{*}$ Transaction cost $\left._{i}\right)$ is negative but insignificant (coefficient $=-0.30, \mathrm{p}$-value $\left.=0.610\right)$. Interestingly, when we use large price drop in Model (3), we find that the effect of transaction 
costs is reduced when we condition on observing a sharp price drop. The interaction term $\beta_{3}$ $\left(\right.$ Trigger $_{i, t}{ }^{*}$ Transaction $_{\text {cost }}$ ) is negative and significant (coefficient $=-0.36, \mathrm{p}$-value $\left.=0.029\right)$. Firms in countries with lower transaction costs (i.e., more efficient judiciary systems) are less likely to be sued, but once we condition on observing a large enough price drop, this effect of transaction costs becomes insignificant.

In Panel C, using U.S. acquisition as measure of transaction costs, we find consistent evidence of transaction costs as a significant driver of the likelihood of litigation. Although observing triggers significantly increases the likelihood of a lawsuit, conditioning on triggers does not change the effect of transaction costs on the litigation likelihood.

\subsection{Litigation outcomes for foreign and domestic firms}

We next examine whether, conditional on a securities class action lawsuit, foreign firms have differential litigation outcomes. The three outcomes we examine are whether the lawsuit is dismissed; when it is not dismissed, then the time to settlement; and the settlement amount. Table 4, Panel B shows the three outcome variable for the foreign and U.S. sample. $54 \%$ of all foreign litigation results in a settlement and $45 \%$ are dismissed. The rate of settlement is slightly higher for the matched U.S. sample at $58 \%$. The outcome is similar for U.S. firms, where $55 \%$ are settled and $44 \%$ dismissed. Next, we use a multivariate logit model to examine the difference in the litigation outcomes of foreign and U.S. matched firms after controlling for the other determinants of litigation outcomes documented in prior studies (Cheng et al., 2010; Brochet and Srinivasan, 2012). We use the following regression mode:

$$
\text { Outcome }_{i, t}=\beta_{0}+\beta_{1} \text { Foreign Indicator }_{i}+\beta_{2-5} \text { Firm_Controls }_{i, t}+\beta_{6-10} \text { Case_Controls }_{c, t}+\varepsilon_{i, t} \text {. }
$$

Table 8 shows the results of estimating equation (5). We consider three outcome variables: dismissals, settlement speed, and settlement amount. Dismissed is an indicator variable that 
equals 1 if the lawsuit is dismissed, and zero otherwise. Settlement speed is the number of days between the lawsuit filing date and settlement date, and settlement amount is measured as the log of the total dollar amount of settlements for settled cases. The coefficient on the foreign indicator $\beta_{I}$ is our main variable of interest, indicating the differential likelihood of each outcome variable for cases against foreign firms relative to U.S. firms. The matched U.S. litigation sample is selected by matching on the log value of market size, an important determinant of lawsuit outcome, within the same FPS industry and fiscal year. In robustness tests, we also create a matched sample based on other characteristics such as the log value of the class period, a class period price drop, and a propensity score matching on the dismissal score based on a dismissal model, which generate qualitatively similar results. The dismissal model includes log value of the class period, class period price drop, and an indicator variable for lawsuits alleges GAAP violations, for lawsuits filed under section 11, for lawsuits where lead plaintiff is an institutional investor (Cheng et al., 2010). This test ensures that the difference in the lawsuit outcomes across domestic and foreign firms are not being driven by the different lawsuit characteristics of the two samples despite the small size of the samples.

Table 8 shows the estimated results of equation (5). We find that there is no difference in the dismissal likelihood and settlement amount for foreign cases relative to U.S. matched cases. The $\beta_{1}$ coefficients on the Foreign Indicator is insignificant in columns (1) and (3) indicating that lawsuits against foreign firms are as likely to be dismissed and that the settlement amounts for non-dismissed cases are similar to what they are for the U.S. matched cases. However, the as seen in column (2) results the settlement speed is slower i.e., it takes significantly longer to settle foreign cases than comparable U.S. cases. Once the lawsuit is filed, the U.S. plaintiffs' bar is as successful against foreign firms as it is against domestic U.S. firms, both in terms of pursuing the 
case to a settlement and the settlement amounts - however it takes longer to do so for foreign cases.

\subsection{Litigation against U.S. listed foreign firms in the home-country}

The lower litigation rate of foreign listed firms relative to U.S. firms suggest that foreign firms face lower level of monitoring from the plaintiffs' bar compared to U.S. firms. However, such litigation, while lower than the rate for a comparable U.S. firm, may still be higher compared to the litigation rate in the home country. In untabulated results, we compare the frequency of lawsuits against the foreign firms listed in the U.S. to the frequency of lawsuits against local firms in these home countries. We use the International Securities Class action Services database provided by Institutional Shareholder Services (ISS) which provides data on private securities class action lawsuits filed in 23 foreign countries. Many of these countries only recently introduced class action lawsuits and have very limited number of lawsuits filed to date. We examine countries with at least 10 securities class actions filed to date (excluding Canada) Australia, Israel, Netherland, and Taiwan - and compare the litigation rate in the home country to the litigation rate in our cross-listed firm sample.

We find that 210 domestic cases were filed in the four countries during our sample period Australia (54), Israel (12), Netherlands (11), Taiwan (133). ${ }^{32}$ The number of cases filed against local firms in the home countries (210) is greater than the 37 cases filed against the cross-listed firms in the U.S. (see Table 3, 1 in Australia, 22 in Israel, 13 in Netherland, and 1 in Taiwan). Yet, if we consider the greater number of firm-years in the four countries (25,493 in Datastream) relative to the cross-listed firm sample (see Table 3, 1,782 firm-years from the four countries), we find that the litigation rate is higher for the cross-listed firms sample (2.1\%) than the frequency

\footnotetext{
${ }^{32}$ The 210 cases include 17 cases which have concurrent cases filed also in the U.S. courts shown in our sample.
} 
observed in the home country in the absence of cross listing $(0.8 \%)$. Thus, the litigation rate of foreign cross-listed firms, while lower than the rate of a comparable U.S. firm, is higher than the rate the foreign firms face in the absence of cross-listing.

\section{Conclusion}

We examine the incidence of securities class action litigation against foreign companies listed in the U.S. and the mechanism driving the litigation risk. Coffee (1999, 2002) and Stulz (1999) advance the "bonding hypothesis" that considers private securities litigation to be one of the mechanisms by which foreign companies bond to a higher quality U.S. regulatory system and thus offer their investors greater protection from corporate malfeasance. Prior literature on U.S. companies shows that litigation risk affects a range of outcomes such as executive compensation, CEO and director turnover, and especially voluntary disclosure behavior.

We find that U.S. listed foreign firms are less likely to be sued than comparable U.S. domestic firms, even those subject to similar ex ante litigation risk. The lower rate is economically meaningful - foreign firms are about half as likely to be sued after controlling for other determinants of being sued. However, even in the case of the few countries with securities class action litigation, foreign firms are more likely to be sued in the U.S. than in their home country lending support to the bonding hypothesis that foreign firms are exposed to tougher securities law enforcement when they list in the U.S.

We find that the lower rate can be driven by two sets of factors. First, foreign firms are less likely to exhibit events such as restatements and sharp stock price drops that are needed in a lawsuit context to allege intentional and wrong prior disclosures on the part of the managers. In the absence of trigger events, the actual incidence of litigation will be lesser even if ex ante litigation risk is similar between U.S. and foreign firms. However, when foreign companies do 
experience litigation triggers such as accounting restatements, missing management forecasts, or sharp drops in stock prices they are as likely to be sued as U.S. firms that experience the same trigger events. This suggests that the U.S. plaintiffs' bar performs its expected role in the presence of actionable events to hold foreign firms accountable as they do for U.S. firms

Secondly, we find that transaction costs of pursuing litigation against foreign firms also play a role. Firms in countries that are farther from the U.S., those that have weaker judicial efficiency in the home country or from countries with a weaker track record of prior U.S. acquisitions are less likely to be targeted by plaintiff investors and attorneys. This suggests that factors that increase the costs to pursue litigation against firms in foreign countries lower the rate of lawsuits against foreign companies listed in the U.S. Even the litigation trigger events do not reduce the impact of the transaction costs.

While the incidence of litigation is lower for foreign firms, the lawsuit outcomes likelihood of dismissal and the amount of settlement, are no different for lawsuits against the foreign-listers compared to outcomes for U.S. domestic firms but the time to settlement is longer for foreign cases. Thus while private enforcement of securities law works for foreign firms as for U.S. firms once the lawsuit is filed some frictions remain as evidenced in the longer settlement period. These results present a nuanced view of the mechanism involved in bonding foreign firms to U.S. regulatory and legal monitoring when they list in the U.S. While the plaintiffs' bar holds foreign firms accountable for alleged securities law violations, the actual incidence of litigation is considerably lower due to the lower extent of actionable litigation triggers and transaction costs. These results have implications for corporate decisions such as voluntary disclosure choices by U.S. listed foreign firms compared to domestic U.S. firms since these choices are partly driven by ex-ante incentives provided by the litigation system. 


\section{References}

Anilowski, C., M. Feng, and D.J. Skinner, 2005. Is guidance a macro factor? The nature and information content of aggregate earnings guidance. Working paper.

Brochet, F., and S. Srinivasan, 2012. Do shareholders hold independent directors accountable? Evidence from firms subject to securities litigation. Working Paper, Harvard Business School.

Cheng, C.S. Agnes, Henry He Huang, Yinghua Li and Gerald Lobo, 2010. Institutional monitoring through shareholder litigation, Journal of Financial Economics, 95, 356-383.

Choi, J., J. Kim, X. Liu, and D. Simunic. 2009. Cross-listing audit fee premiums: Theory and evidence. The Accounting Review 84 (5): 1429-1463.

Chuk, E., D. Matsumoto, and G. S. Miller. 2012. Assessing Methods of Identifying Management Forecasts: CIG Vs. Researcher Collected. Journal of Accounting and Economics.

Coffee, J. C. Jr., 1999. The future of history: The prospects for global convergence in corporate governance and its implications. Northwestern University Law Review 93, 641-708.

Coffee, J. C. Jr., 2002. Racing towards the top? The impact of cross-listings and stock market competition on international corporate governance. Columbia Law Review 102, 1757-1831.

Dai, Z., W. Jin and W. Zhang, 2009. Litigation, corporate governance and executive compensation. Working paper, University of Texas-Dallas.

DuCharme, L. L., P. H. Malatesta, and S. E. Sefcik, 2004. Journal of Financial Economics, 71, 27-49.

Erel I., R. Liao, and M Weisbach, 2012, Determinants of Cross-border Mergers and Acquisitions, Journal of Finance The Journal of Finance, 67, 1045-1082.

Ferris, S. P., T. Jandik, R. M. Lawless and A.Makhija, 2007. Derivative Lawsuits as a Corporate Governance Mechanism: Empirical Evidence on Board Changes Surrounding Filings. Journal of Financial and Quantitative Analysis, 42, 143-166.

Fich, E.M., and A. Shivdasani, 2007. Financial fraud, director reputation, and shareholder wealth. Journal of Financial Economics 86 (2): 306-336.

Field, L., M. Lowry, and S. Shu, 2005. Does disclosure deter or trigger litigation? Journal of Accounting and Economics 39, 487-507.

Francis, J., D. Philbrick, and K. Schipper, 1994. Shareholder litigation and corporate disclosures. Journal of Accounting Research 32, 137-164.

Gagnon L., and G.A. Karolyi, 2011. The economic consequences of the U.S. Supreme Court's Morrison v. National Australia Bank decision for foreign stocks cross-listed in U.S. markets. Working Paper, Johnson Graduate School of Management.

Gande, A., and D. P. Miller, 2012. Why do U.S. securities laws matter to non-U.S. firms? Evidence from private class-action lawsuits. Working Paper, Southern Methodist University.

Hanley, K.W. and G. Hoberg, 2012. Litigation risk, strategic disclosure and the underpricing of initial public offerings. Journal of Financial Economics, 103, 235-254. 
Hennes, K. M., A. J. Leone, and B. P. Miller, 2008. The importance of distinguishing errors from irregularities in restatement research: The case of restatements and CEO/CFO turnover. The Accounting Review 83, 1487-1519.

Jackson, H.E., and M.J. Roe, 2009. Public and private enforcement of securities laws: Resource-based evidence. Journal of Financial Economics 93(2): 207-238.

Johnson, M. F., K. K. Nelson, and A. C. Pritchard. 2007. Do the merits matter more? The impact of the Private Securities Litigation Reform Act. Journal of Law, Economics, and Organization 23 (3): 627652.

Jones, C. L., and S.E. Weingram, 1996. The determinants of 10b-5 litigation risk. Working paper.

Kaufman, M. J., and J. M. Wunderlich, 2011. The judicial access barriers to remedies for securities fraud. Law and Contemporary Problems, forthcoming.

Kim, I., and D.J. Skinner, 2012. Measuring securities litigation risk. Journal of Accounting and Economics 53, 290-310.

Lang, M., J. Smith Raedy, and M. H. Yetman, 2003. How representative are firms that are cross-listed in the United States? An analysis of accounting quality. Journal of Accounting Research 41, 363-386.

Lang, M., J. S. Raedy, and W. Wilson, 2006. Earnings management and cross listing: Are reconciled earnings comparable to US earnings? Journal of Accounting and Economics 42, 255-283.

Lerach, W.S., 1989. Securities Class Actions and Derivative Litigations Involving Public Companies: A Plaintiff's Perspective. American Bar Association.

Licht, A., X. Li, J. Siegel, 2011. What makes the bonding stick? A natural experiment involving the supreme court and cross-listed firms. Working paper, Harvard Business School.

Lowry, M. and S. Shu, 2002. Litigation risk and IPO underpricing. Journal of Financial Economics, 65, 309-335.

Mark, G., 2011. Confidential witnesses in securities litigation. Journal of Corporation Law 36 (3): 551-606.

Matsumoto, D., 2002. Management's incentives to avoid negative earnings surprises. The Accounting Review 77(3): 483-514.

McTier, B. C. and J. K. Wald. 2011. The causes and consequences of securities class action litigation. Journal of Corporate Finance, 17, 649-665.

Mian, A., 2006. Distance constraints: The limits of foreign lending in poor economies. Journal of Finance 61 (3), 1465-505.

Niehaus, Greg and Greg Roth, 1999. Insider Trading, Equity Issues, and CEO Turnover in Firms Subject to Class Action. Financial Management, 28, 52-72.

NERA Economic Consulting, 2011. Recent trends in securities class action litigation: 2011 year-end review.

Palmrose, Z-V., and S. Scholz. 2004. The circumstances and legal consequences of non-GAAP reporting: Evidence from restatements. Contemporary Accounting Research 21, 139-80. 
Portes, R., and H. Rey, 2005. The determinants of cross-border equity flows. Journal of International Economics 65 (2005), 269-296.

Rogers, J. L. 2008. Disclosure quality and management trading incentives. Journal of Accounting Research 46 (5): 1265-1296.

Rogers, J. L., and A. Van Buskirk, 2009. Shareholder litigation and changes in disclosure behavior. Journal of Accounting and Economics 47, 136-156.

Rogers, J. L., A. Van Buskirk, and Sarah Zechman 2011 Disclosure tone and shareholder litigation, The Accounting Review, (2011) Vol. 86 (6), pp. 2155-2183.

SEC, 2004. Final Rule: Additional Form 8-K Disclosure Requirements and Acceleration of Filing Date. [Release No. 33-8400; 34-49424; File No. S7-22-02]

SEC, 2012. Study on the Cross-border Scope of the Private Right of Action Under Section 10(b) of the Security Exchange Act of 1934, As Required by Section 929Y of the Dodd-Frank Wall Street Reform and Consumer Protection Act, April 2012.

Seetharaman, A., F. Gul, and S. Lynn, 2002. Litigation risk and audit fees: Evidence from U.K. firms crosslisted on U.S. markets, Journal of Accounting and Economics 33, 91-115.

Siegel, J., 2005. Can foreign firms bond themselves effectively by renting U.S. securities laws? Journal of Financial Economics 75, 319-359.

Skinner, D.J., 1994. Why firms voluntarily disclose bad news. Journal of Accounting Research 32, 38-60.

Skinner, D.J., 1997. Earnings disclosure and stockholder lawsuits. Journal of Accounting and Economics 23, (3) 249-282.

Srinivasan, S., A. S. Wahid, and G. Yu, 2012. Admitting mistakes: An analysis of restatements by foreign firms listed in the U.S. Working paper, Harvard University.

Stulz, R.M., 1999. Globalization, corporate finance, and the cost of capital. Journal of Applied Corporate Finance 12(3): 8-25. 


\section{Appendix: Variable Definitions}

\begin{tabular}{|c|c|}
\hline Variable & Description \\
\hline $\begin{array}{l}\text { Ex-ante litigation risk } \\
\text { FPS Industry }\end{array}$ & $\begin{array}{l}\text { Indicator variable that equals } 1 \text { if the firm is in industries subject to a high } \\
\text { litigation risk, } 0 \text { otherwise. Industries with a high litigation risk is based on } \\
\text { Francis et al. (1994) and include the biotech (sic codes 2833-2836 and 8731- } \\
\text { 8734), computer (3570-3577 and 7370-7374), electronics (3600-3674), and } \\
\text { retail (5200-5961) industries. }\end{array}$ \\
\hline Sales growth $_{i, t-1}$ & $\begin{array}{l}\text { Prior year sales growth based on changes in sales from year } \mathrm{t}-2 \text { to } \mathrm{t}-1 \text { sales, } \\
\text { scaled by beginning of year } \mathrm{t}-1 \text { total assets. }\end{array}$ \\
\hline Size $_{i, t-1}$ & Natural log of total assets at the end of year $t-1$. \\
\hline Prior return $_{i, t-1}$ & $\begin{array}{l}\text { Market-adjusted 12-month stock returns (the raw return minus the market return) } \\
\text { For sued firms, the accumulation periods ends in the end of the fiscal year prior } \\
\text { to the lawsuit filing year. For firms with no lawsuits, the accumulation period } \\
\text { ends at the fiscal end of year t-1. }\end{array}$ \\
\hline Prior return skewness $s_{i, t-1}$ & Skewness of the firm's 12-month return for year t-1. \\
\hline Prior return volatility $_{i, t-1}$ & Standard deviation of the 12-month return for year $\mathrm{t}-1$. \\
\hline Prior turnover,$t-1_{1}$ & $\begin{array}{l}\text { Trading volume accumulated over the } 12 \text {-month period scaled by the } \\
\text { beginning of year } t-1 \text { shares outstanding. Note that the turnover values are } \\
\text { further divided by } 10,000 \text { to present meaningful coefficients. }\end{array}$ \\
\hline
\end{tabular}

Litigation triggers

Material restatement $t_{i, t}$

Missing

management gudiance $_{i, t}$

Large price drop $_{i, t}$
Equal to 1 for non-sued firms if the company files at least one non-stealth restatement, i.e., a restatement filed in the form of 6-k, 8-k or a press release in fiscal year $t$, and zero otherwise. For sued firms, equal to 1 if the company files at least one non-stealth restatement between the period from the beginning of the fiscal year in which the lawsuit is filed and the filing date, and zero otherwise. The final rule requires material restatements to be disclosed in a more visible, i.e., non-stealth, manner.

Equal to 1 if the company's previous-fiscal-yearend EPS (basic EPS including extraordinary items) fails to meet management guidance for that year, and zero otherwise. Using the classification method in Anilowski et al 2005, management guidance is categorized as point, range, Maximum, Minimum, or qualitative guidance. The year-end EPS is defined as missing management guidance if EPS is lower than the point forecast number, or the mean of the range forecast numbers, or the Minimum forecast number.

Equal to 1 for non-sued firms if the company has at least one weekly return that is greater than negative $30 \%$ in the fiscal year, and zero otherwise. For sued firms, equal to 1 if the company has at least one weekly return greater than negative $30 \%$ during the period from the beginning of the fiscal year in which the lawsuit is filed and the filing date, and zero otherwise.
Transaction costs

Geographic distance ${ }_{c}$
The log of the shortest distance between the capital city of the home country of the foreign firms and New York using the great circle formula. 
Judicial efficiency ${ }_{c}$

U.S. acquisitions ${ }_{c}$

\section{Settlement characteristics}

Dismissed

Dismissal Speed

Settlement Amount

GAAP

Section 11

Lead Institutional Plaintiff

Class Period Length

Class Period Price Drop

Market Size

Sales Growth

Share Turnover
A 0-10 score that assesses the efficiency and integrity of the legal environment as it affects business, produced by the country risk rating agency International Country Risk (ICR). The measure represents investors' assessment of conditions in the country in question, with lower scores representing lower efficiency levels.

Log value of total number of cross-border acquisitions in each foreign country by U.S. acquirers from 1990 to 2007. (Source: Thomson SDC Platinum database)

Equal to 1 if the lawsuit status is dismissed and zero otherwise.

The number of days between the lawsuit filing date and its settlement date. The log of total dollar amount of settlement for settled cases. Equal to 1 if the lawsuit alleges violation of U.S. GAAP, zero otherwise. Equal to 1 if the lawsuit is filed under Section 11 of the Securities Act of 1933, zero otherwise.

Equal to 1 if the lead plaintiff is an institutional investor, zero otherwise. Log value of the number of days between the beginning and the end of the class period.

The inverse of the cumulative stock return from the highest price during the class period to the end of the class period.

The log of market capitalization as of the beginning of the fiscal year during which the lawsuit is filed.

Current year $(\mathrm{t})$ sales less prior year (t-1) sales scaled by the beginning of year $t$ 's total assets.

The average daily trading volume as a percentage of shares outstanding during the class period. 
Table 1

Sample selection

cases

\# of firms \# of firm-years

Number of Litigation Cases in fiscal year 1996-2010

Less: IPO Cases

3,672

Less: Analyst Cases

(307)

Less: MBS, ABS, Other accounts

3,270

Less: Missing Identifiers

(379)

2,891

(744)

(15)

$19,467 \quad 151,687$

Less: Incomplete information to estimate litigation risk

Less: Incomplete information for stock price drop

\begin{tabular}{lrrr}
\hline Total useable observations: & $\mathbf{2 , 1 3 2}$ & $\mathbf{1 2 , 1 2 6}$ & $\mathbf{8 6 , 2 5 5}$ \\
Foreign Company Cases & 178 & 1,192 & 8,243 \\
US Company Cases & 1,954 & 10,934 & 78,012 \\
\hline
\end{tabular}

Notes: Table 1 shows the sample formation of securities class action lawsuit filings from the ISS Securities Class Action Clearinghouse database from 1996 to 2010. We drop litigation cases whose company names cannot be found in Compustat (missing identifiers). We drop all firm-years that do not have complete data for ex ante litigation risk factors and concurrent price drop triggers. The final sample is 86,255 observations (12,126 unique firms) and 2,132 litigation cases, with 78,012 U.S. firm-years (10,934 firms) and 8,243 foreign cross-listed firm-years (1,192 firms). Canadian firms and litigation cases are excluded from the sample. 
Table 2

Descriptive statistics of foreign firms and the matched U.S. firm sample

\begin{tabular}{|c|c|c|c|c|c|c|c|c|}
\hline \multirow[t]{2}{*}{ Variables } & \multicolumn{2}{|c|}{$\begin{array}{l}\text { (1) Foreign firms } \\
(\mathrm{N}=8,243)\end{array}$} & \multicolumn{2}{|c|}{$\begin{array}{l}\text { (2) Matched US firms } \\
(\mathrm{N}=8,003)\end{array}$} & \multicolumn{2}{|c|}{$\begin{array}{l}\text { (3) U.S. firms } \\
(\mathrm{N}=77,870)\end{array}$} & \multirow{2}{*}{$\begin{array}{c}\text { Diff in mean: } \\
(1)=(2) \\
P \text {-values: }\end{array}$} & \multirow{2}{*}{$\begin{array}{l}\text { Diff in mean: } \\
(1)=(3) \\
P \text {-values: }\end{array}$} \\
\hline & Mean & Median & Mean & Median & Mean & Median & & \\
\hline Litigation risk score & -3.49 & -3.54 & -3.52 & -3.55 & -4.07 & -4.13 & 0.000 & 0.000 \\
\hline \multicolumn{9}{|l|}{ Firm characteristics } \\
\hline FPS Industry & 0.30 & 0.00 & 0.30 & 0.00 & 0.28 & 0.00 & 0.001 & 0.000 \\
\hline Size $_{t-1}$ & 7.18 & 7.21 & 6.71 & 6.61 & 5.71 & 5.66 & 0.000 & 0.000 \\
\hline Sales growth ${ }_{t-1}$ & 0.11 & 0.05 & 0.17 & 0.05 & 0.14 & 0.04 & 0.000 & 0.000 \\
\hline Prior year return ${ }_{t-1}$ & 0.05 & -0.06 & 0.01 & -0.11 & 0.01 & -0.10 & 0.000 & 0.000 \\
\hline Skewness of prior returns $t_{t-1}$ & 0.47 & 0.34 & 0.28 & 0.27 & 0.48 & 0.38 & 0.471 & 0.788 \\
\hline Prior year return volatility ${ }_{t-1}$ & 0.04 & 0.03 & 0.04 & 0.03 & 0.04 & 0.03 & 0.000 & 0.000 \\
\hline Prior year turnover $r_{t-1}$ & 0.24 & 0.14 & 0.24 & 0.15 & 0.17 & 0.10 & 0.000 & 0.000 \\
\hline \multicolumn{9}{|l|}{ Litigation triggers } \\
\hline Material restatement ${ }_{\mathrm{t}}$ & 0.01 & 0.00 & 0.04 & 0.00 & 0.03 & 0.00 & 0.000 & 0.000 \\
\hline Missing management guidance ${ }_{t}$ & 0.04 & 0.00 & 0.14 & 0.00 & 0.12 & 0.00 & 0.000 & 0.000 \\
\hline Drop $30_{t}$ & 0.09 & 0.00 & 0.13 & 0.00 & 0.12 & 0.00 & 0.000 & 0.000 \\
\hline
\end{tabular}

Notes: Table 2 shows the descriptive statistics of the firm characteristics and litigation triggers for the foreign crosslisted sample (column 1), the matched U.S. sample (column 2), and the entire U.S. sample (column 3). The match U.S. sample is matched based on the closest ex ante litigation risk score within the same two-digit SIC code and fiscal year. The litigation risk score is calculated based on the U.S. litigation model using the litigation risk factors described in the text. All variables are defined in the appendix. The t-tests in the last two columns show two-sided p-values. 
Table 3 Distribution of securities class action lawsuits against foreign firms listed in the U.S.

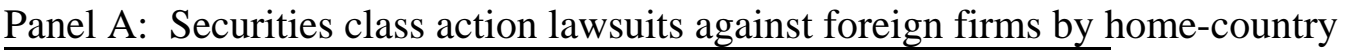

\begin{tabular}{|c|c|c|c|c|c|c|c|c|c|}
\hline \multirow[b]{2}{*}{ Countries } & \multirow[b]{2}{*}{$\begin{array}{c}(1) \\
\text { \# of } \\
\text { lawsuits }\end{array}$} & \multirow[b]{2}{*}{$\begin{array}{c}\text { (2) } \\
\text { Total \# of } \\
\text { firm-years } \\
\end{array}$} & \multirow[b]{2}{*}{$\begin{array}{c}(3)=(1) /(2) \\
\% \text { of firm-years } \\
\text { with laws uits }\end{array}$} & \multirow[b]{2}{*}{$\begin{array}{c}\text { (4) } \\
\% \text { of firms } \\
\text { with laws laits } \\
\end{array}$} & & & & & \\
\hline & & & & & Countries & $\begin{array}{c}(1) \\
\text { \# of } \\
\text { lawsuits }\end{array}$ & $\begin{array}{c}\text { (2) } \\
\text { Total \# of } \\
\text { firm-years }\end{array}$ & $\begin{array}{c}(3)=(1) /(2) \\
\% \text { of firm-years } \\
\text { with lawsuits }\end{array}$ & $\begin{array}{c}\text { (4) } \\
\% \text { of firms } \\
\text { with lawsuits }\end{array}$ \\
\hline ARGENTINA & 1 & 153 & 0.65 & 5.56 & KOREA & 3 & 110 & 2.73 & 14.29 \\
\hline AUSTRALIA & 1 & 222 & 0.45 & 2.94 & LIBERIA & 0 & 15 & 0.00 & 0.00 \\
\hline AUSTRIA & 0 & 7 & 0.00 & 0.00 & LUXEMBOURG & 1 & 105 & 0.95 & 6.25 \\
\hline BAHAMAS & 0 & 29 & 0.00 & 0.00 & MALAYSIA & 0 & 1 & 0.00 & 0.00 \\
\hline BELGIUM & 3 & 33 & 9.09 & 28.57 & MARSHALL ISLANI & 0 & 5 & 0.00 & 0.00 \\
\hline BERMUDA & 14 & 447 & 3.13 & 16.90 & MEXICO & 1 & 307 & 0.33 & 2.56 \\
\hline BOLIVIA & 0 & 1 & 0.00 & 0.00 & MONACO & 0 & 12 & 0.00 & 0.00 \\
\hline BRAZIL & 1 & 98 & 1.02 & 6.25 & NETHERLANDS & 13 & 402 & 3.23 & 22.00 \\
\hline CAYMAN ISLANDS & 5 & 68 & 7.35 & 40.00 & NETHERLANDS AN & 0 & 47 & 0.00 & 0.00 \\
\hline CHILE & 0 & 236 & 0.00 & 0.00 & NEW ZEALAND & 0 & 45 & 0.00 & 0.00 \\
\hline CHINA & 27 & 677 & 3.99 & 13.71 & NORWAY & 0 & 63 & 0.00 & 0.00 \\
\hline COLOMBIA & 0 & 7 & 0.00 & 0.00 & PANAMA & 3 & 62 & 4.84 & 33.33 \\
\hline CZECH REPUBLIC & 0 & 1 & 0.00 & 0.00 & PAPUA NEW GUINI & 0 & 14 & 0.00 & 0.00 \\
\hline DENMARK & 0 & 41 & 0.00 & 0.00 & PERU & 0 & 36 & 0.00 & 0.00 \\
\hline DOMINICAN REP. & 0 & 6 & 0.00 & 0.00 & PHILLIPPINES & 0 & 28 & 0.00 & 0.00 \\
\hline FINLAND & 2 & 56 & 3.57 & 14.29 & POLAND & 0 & 3 & 0.00 & 0.00 \\
\hline FRANCE & 9 & 330 & 2.73 & 20.51 & RUSSIA & 1 & 54 & 1.85 & 14.29 \\
\hline GERMANY & 10 & 201 & 4.98 & 25.00 & SINGAPORE & 1 & 92 & 1.09 & 10.00 \\
\hline GHANA & 1 & 7 & 14.29 & 100.00 & SOUTH AFRICA & 2 & 135 & 1.48 & 11.11 \\
\hline GREECE & 0 & 147 & 0.00 & 0.00 & SPAIN & 1 & 104 & 0.96 & 9.09 \\
\hline HONG KONG & 3 & 333 & 0.90 & 5.77 & SWEDEN & 1 & 109 & 0.92 & 5.56 \\
\hline HUNGARY & 0 & 27 & 0.00 & 0.00 & SWITZERLAND & 15 & 250 & 6.00 & 34.62 \\
\hline ICELAND & 1 & 8 & 12.50 & 100.00 & TAIWAN & 1 & 112 & 0.89 & 7.14 \\
\hline INDIA & 0 & 126 & 0.00 & 0.00 & THAILAND & 1 & 7 & 14.29 & 50.00 \\
\hline INDONESIA & 0 & 44 & 0.00 & 0.00 & TURKEY & 0 & 11 & 0.00 & 0.00 \\
\hline IRELAND & 7 & 310 & 2.26 & 11.43 & UK & 22 & 877 & 2.51 & 13.77 \\
\hline ISRAEL & 22 & 1046 & 2.10 & 13.74 & VENEZUELA & 0 & 20 & 0.00 & 0.00 \\
\hline ITALY & 0 & 143 & 0.00 & 0.00 & VIRGIN ISLANDS & 2 & 16 & 12.50 & 50.00 \\
\hline JAPAN & 3 & 389 & 0.77 & 2.63 & Total foreign firms & 178 & 8,243 & 2.16 & 12.16 \\
\hline JORDAN & 0 & 4 & 0.00 & 0.00 & Matched US firms & 310 & 8,243 & 3.76 & 23.37 \\
\hline KAZAKHSTAN & 0 & 4 & 0.00 & 0.00 & US firms & 1,954 & 78,012 & 2.50 & 14.43 \\
\hline
\end{tabular}




\section{Table 3 (Continued)}

Panel B: Securities class action lawsuits against foreign firms by year of lawsuit filing All foreign firms

All Matched U.S. firms

\begin{tabular}{|c|c|c|c|c|c|c|c|c|c|}
\hline Year & $\begin{array}{c}\text { (1) } \\
\text { \# of } \\
\text { lawsuits }\end{array}$ & $\begin{array}{c}\text { (2) } \\
\text { Total \# of } \\
\text { firm-years }\end{array}$ & $\begin{array}{c}(3)=(1) /(2) \\
\% \text { of firm-years } \\
\text { with lawsuits }\end{array}$ & $\begin{array}{c}\text { (4) } \\
\% \text { of firms } \\
\text { with lawsuits } \\
\end{array}$ & Year & $\begin{array}{c}\text { (1) } \\
\text { \# of } \\
\text { lawsuits }\end{array}$ & $\begin{array}{c}\text { (2) } \\
\text { Total \# of } \\
\text { firm-years }\end{array}$ & $\begin{array}{c}(3)=(1) /(2) \\
\% \text { of firm- } \\
\text { years } \\
\text { with lawsuits }\end{array}$ & $\begin{array}{c}(4) \\
\% \text { of firms } \\
\text { with } \\
\text { lawsuits } \\
\end{array}$ \\
\hline 1996 & 5 & 348 & 1.44 & 1.44 & 1996 & 2 & 348 & 0.57 & 0.57 \\
\hline 1997 & 2 & 432 & 0.46 & 0.46 & 1997 & 11 & 432 & 2.55 & 1.78 \\
\hline 1998 & 11 & 505 & 2.18 & 2.18 & 1998 & 16 & 505 & 3.17 & 2.24 \\
\hline 1999 & 6 & 529 & 1.13 & 1.13 & 1999 & 18 & 529 & 3.40 & 2.52 \\
\hline 2000 & 12 & 553 & 2.17 & 2.17 & 2000 & 19 & 553 & 3.44 & 2.47 \\
\hline 2001 & 8 & 586 & 1.37 & 1.37 & 2001 & 20 & 586 & 3.41 & 5.89 \\
\hline 2002 & 12 & 609 & 1.97 & 1.97 & 2002 & 33 & 609 & 5.42 & 3.17 \\
\hline 2003 & 16 & 591 & 2.71 & 2.71 & 2003 & 21 & 591 & 3.55 & 2.74 \\
\hline 2004 & 18 & 573 & 3.14 & 2.97 & 2004 & 26 & 573 & 4.54 & 3.30 \\
\hline 2005 & 11 & 572 & 1.92 & 1.92 & 2005 & 23 & 572 & 4.02 & 2.68 \\
\hline 2006 & 9 & 573 & 1.57 & 1.57 & 2006 & 18 & 573 & 3.14 & 1.88 \\
\hline 2007 & 22 & 581 & 3.79 & 3.62 & 2007 & 28 & 581 & 4.82 & 2.65 \\
\hline 2008 & 9 & 582 & 1.55 & 1.55 & 2008 & 34 & 582 & 5.84 & 2.61 \\
\hline 2009 & 12 & 587 & 2.04 & 1.88 & 2009 & 18 & 587 & 3.07 & 2.25 \\
\hline 2010 & 25 & 622 & 4.02 & 3.24 & 2010 & 23 & 622 & 3.70 & 3.29 \\
\hline Total fore ign firms & 178 & 8,243 & 2.16 & 12.16 & Total foreign firt & 310 & 8,243 & 3.76 & 23.37 \\
\hline
\end{tabular}

Notes: Table 3 shows the distribution of securities class action lawsuits by home country (Panel A) and litigation filing year (Panel B). In each panel, column 1 shows the number of lawsuits and column 2 shows the number of firm-year observations. Column 3(4) gives the percentage of lawsuits among all firm-year (firm) observations. Country affiliation of a cross-listed firm is determined by the location of its headquarters or its country of incorporation if the headquarters is in the U.S. The matched U.S. firm-year is constructed by matching firm-years with a similar level of litigation risk as the foreign firm. We choose the U.S. firm-year with the closest ex ante litigation risk score within the same two-digit SIC code and fiscal year. The litigation risk score is calculated based on the U.S. litigation model using the litigation risk factors described in the text. 


\section{Table 4}

\section{Litigation characteristics of foreign firms and matched U.S. firm sample}

Panel A: Frequency of class action against foreign and U.S. matched firm-years

\begin{tabular}{|c|c|c|c|c|c|c|c|c|}
\hline \multirow{3}{*}{ \# of class action lawsuits } & \multicolumn{2}{|c|}{$\begin{array}{c}(1) \\
\text { Foreign firms }\end{array}$} & \multicolumn{2}{|c|}{$\begin{array}{c}\text { (2) } \\
\text { Matched US firms }\end{array}$} & \multicolumn{2}{|c|}{$\begin{array}{c}\text { (3) } \\
\text { All U.S. firms }\end{array}$} & \multicolumn{2}{|c|}{$\begin{array}{l}\text { P-values P-values } \\
(1)=(2) \quad(1)=(3)\end{array}$} \\
\hline & \# of firm-year: & Stat & \# of firm-years & \multirow{2}{*}{$\frac{\text { Stat }}{310}$} & \# of firm-years & Stat & & \\
\hline & 8,243 & 178 & 8,243 & & 78,012 & 1,954 & & \\
\hline$\%$ of firm-years with lawsuits & 8,243 & $2.16 \%$ & 8,243 & $3.76 \%$ & 78,012 & $2.50 \%$ & 0.000 & 0.042 \\
\hline \multicolumn{9}{|c|}{ Panel B: Characteristics of class actions against foreign and U.S. matched firms } \\
\hline & \multicolumn{2}{|c|}{$\begin{array}{c}(1) \\
\text { Foreign firms }\end{array}$} & \multicolumn{2}{|c|}{$\begin{array}{c}(2) \\
\text { Matched US firms }\end{array}$} & \multicolumn{2}{|c|}{$\begin{array}{c}\text { (3) } \\
\text { All U.S. firms } \\
\end{array}$} & \multirow[t]{2}{*}{$\begin{array}{c}\text { P-values } \\
(1)=(2)\end{array}$} & \multirow[t]{2}{*}{$\begin{array}{c}\text { P-values } \\
(1)=(3)\end{array}$} \\
\hline & \# of cases & Mean & \# of cases & Mean & \# of cases & Mean & & \\
\hline \multicolumn{9}{|l|}{ Laws uit characte ristics } \\
\hline$\%$ of GAAP violation & 126 & 0.56 & 126 & 0.55 & 1484 & 0.57 & 0.733 & 0.898 \\
\hline$\%$ of Section 11 violation & 126 & 0.20 & 126 & 0.23 & 1484 & 0.16 & 0.467 & 0.359 \\
\hline Institutional lead plaintiff & 126 & 0.47 & 126 & 0.53 & 1484 & 0.41 & 0.229 & 0.237 \\
\hline Class period length (log) & 126 & 5.89 & 126 & 5.69 & 1484 & 5.67 & 0.011 & 0.045 \\
\hline \multicolumn{9}{|l|}{ Lawsuit resolution } \\
\hline \multicolumn{9}{|l|}{ Outcomes } \\
\hline$\%$ settled & 68 & 0.54 & 73 & 0.58 & 822 & 0.55 & 0.120 & 0.760 \\
\hline$\%$ dismissed & 57 & 0.45 & 52 & 0.41 & 655 & 0.44 & 0.510 & 0.813 \\
\hline$\%$ class certified & 1 & 0.01 & 1 & 0.01 & 7 & 0.01 & 1.000 & 0.693 \\
\hline \multicolumn{9}{|l|}{ Settlement } \\
\hline Settlement amount (\$ million) & 68 & 87.33 & 68 & 22.40 & 818 & 41.39 & 0.194 & 0.359 \\
\hline Time to settle (days) & 68 & 1310.57 & 68 & 1100.29 & 818 & 1152.16 & 0.014 & 0.046 \\
\hline \multicolumn{9}{|c|}{ Lawsuit allegations (out of 126 cases) } \\
\hline Accounting issues & 57 & 0.45 & 52 & 0.41 & 586 & 0.39 & & \\
\hline Earnings guidance & 52 & 0.41 & 61 & 0.48 & 583 & 0.39 & & \\
\hline Large price drop & 26 & 0.21 & 28 & 0.22 & 292 & 0.20 & & \\
\hline Others & 24 & 0.19 & 23 & 0.18 & 275 & 0.19 & & \\
\hline Other product/ defects & 20 & 0.16 & 23 & 0.18 & 313 & 0.21 & & \\
\hline Merger integration issues & 19 & 0.15 & 6 & 0.05 & 143 & 0.10 & & \\
\hline Financial Product/ defects & 13 & 0.10 & 16 & 0.13 & 107 & 0.07 & & \\
\hline Industry-related & 8 & 0.06 & 5 & 0.04 & 48 & 0.03 & & \\
\hline Insider trading & 6 & 0.05 & 12 & 0.10 & 180 & 0.12 & & \\
\hline
\end{tabular}

Notes: Panel $A$ shows the number and percentage of lawsuits for the foreign cross-listed sample (column 1), the matched U.S. sample (column 2), and the entire U.S. sample (column 3). The matched U.S. firm-year is constructed by matching firm-years with a similar level of litigation risk as the foreign firm. We choose the U.S. firm-year with the closest ex ante litigation risk score within the same two-digit SIC code and fiscal year. The litigation risk score is calculated based on the U.S. litigation model using the litigation risk factors described in the text. Panel B presents the lawsuit characteristics of a subsample used in later regressions (Table 8) that study the differences in resolutions and outcomes between lawsuits against foreign firms and U.S. firms. This subsample excludes 21 active cases and 31 cases missing a class period and data to calculate period price drop, market value, or the year-end's sales. A new U.S. sample is matched to the 126-case foreign lawsuit sample by year, FPS industry membership, and firm size. All variables are defined in the appendix. The t-tests in the last two columns show two-sided p-values. 
Table 5

Litigation risk for foreign firms and the matched U.S. firms sample

\begin{tabular}{|c|c|c|c|c|}
\hline & $\begin{array}{c}\text { (1) } \\
\text { Foreign \& US } \\
\text { matched firms }\end{array}$ & $\begin{array}{c}(2) \\
\text { Foreign only }\end{array}$ & $\begin{array}{c}\text { (3) } \\
\text { Foreign only }\end{array}$ & $\begin{array}{c}(4) \\
\text { Foreign only }\end{array}$ \\
\hline Fore ign indicator & $\begin{array}{c}\mathbf{- 0 . 5 9} * * * \\
(0.000)\end{array}$ & & & \\
\hline Transaction cost & & $\begin{array}{c}\text { Geographic } \\
\text { distance } \\
\mathbf{- 0 . 4 0}^{* * *} \\
(0.002)\end{array}$ & $\begin{array}{c}\text { Judicial } \\
\text { Efficiency } \\
\mathbf{0 . 2 6 * * *} \\
(0.001)\end{array}$ & $\begin{array}{c}U . S . \\
\text { acquisitions } \\
\mathbf{0 . 2 0} * * * \\
(0.002)\end{array}$ \\
\hline \multicolumn{5}{|l|}{ Firm characteristics } \\
\hline FPS Industry & $\begin{array}{c}0.48^{* * * *} \\
(0.000)\end{array}$ & $\begin{array}{c}0.36^{*} \\
(0.071)\end{array}$ & $\begin{array}{l}0.45^{* *} \\
(0.044)\end{array}$ & $\begin{array}{c}0.33 \\
(0.123)\end{array}$ \\
\hline Size $t-1$ & $\begin{array}{c}0.28^{* * *} \\
(0.000)\end{array}$ & $\begin{array}{l}0.14^{* * * *} \\
(0.005)\end{array}$ & $\begin{array}{l}0.20^{* * * *} \\
(0.000)\end{array}$ & $\begin{array}{l}0.12 * * \\
(0.025)\end{array}$ \\
\hline Sales growth $\mathrm{t}-1$ & $\begin{array}{c}0.48^{* * *} \\
(0.000)\end{array}$ & $\begin{array}{c}0.56^{* * *} \\
(0.001)\end{array}$ & $\begin{array}{c}0.67^{* * *} \\
(0.005)\end{array}$ & $\begin{array}{c}0.59^{* * * *} \\
(0.001)\end{array}$ \\
\hline Prior year return $\mathrm{t}-1$ & $\begin{array}{c}-0.26^{* * * *} \\
(0.006)\end{array}$ & $\begin{array}{c}-0.19 \\
(0.158)\end{array}$ & $\begin{array}{c}-0.28 \\
(0.150)\end{array}$ & $\begin{array}{c}-0.20 \\
(0.146)\end{array}$ \\
\hline Prior return skewness $\mathrm{t}-1$ & $\begin{array}{c}-0.24 * * * \\
(0.000)\end{array}$ & $\begin{array}{l}-0.20^{*} \\
(0.084)\end{array}$ & $\begin{array}{c}-0.21 \\
(0.183)\end{array}$ & $\begin{array}{c}-0.20 \\
(0.138)\end{array}$ \\
\hline Prior return volatility t-1 & $\begin{array}{c}19.28^{* * *} \\
(0.000)\end{array}$ & $\begin{array}{c}11.65^{* *} \\
(0.026)\end{array}$ & $\begin{array}{c}3.09 \\
(0.596)\end{array}$ & $\begin{array}{c}7.23 \\
(0.224)\end{array}$ \\
\hline Prior year turnover ${ }_{t-1}$ & $\begin{array}{l}0.47^{* * *} \\
(0.000)\end{array}$ & $\begin{array}{l}0.37 * * \\
(0.041)\end{array}$ & $\begin{array}{c}0.39 * \\
(0.077)\end{array}$ & $\begin{array}{c}0.35^{*} \\
(0.063)\end{array}$ \\
\hline Constant & $\begin{array}{c}-6.23^{* * *} \\
(0.000)\end{array}$ & $\begin{array}{c}-1.36 \\
(0.228)\end{array}$ & $\begin{array}{c}-7.78^{* * *} \\
(0.000)\end{array}$ & $\begin{array}{c}-5.60^{* * *} \\
(0.000)\end{array}$ \\
\hline Year FE & $\mathrm{Y}$ & $\mathrm{Y}$ & $\mathrm{Y}$ & $\mathrm{Y}$ \\
\hline Observations & 16,486 & 8,243 & 6,635 & 7,498 \\
\hline Pseudo R-squared & 0.0725 & 0.0497 & 0.0737 & 0.0561 \\
\hline
\end{tabular}

Notes: This table reports the litigation risk of a foreign firm relative to the matched U.S. sample. Columns (1) report the estimation from a logistic regression of equation (1). The dependent variable is an indicator variable that takes a value of 1 if the firm is sued in the particular year, and 0 otherwise. The foreign indicator is equal to 1 for foreign cross-listed firms and 0 for U.S. firms. Columns (2) to (4) report the estimation from a logistic regression of equation (2) with the same dependent variable. Three different proxies for transaction costs are tested: geographic distance, judicial efficiency, and U.S. acquisitions in the foreign country. All variables are defined in the appendix. Standard errors are clustered at the firm level. Significance is denoted by $* * *, * *$, and for $1 \%$, $5 \%$, and $10 \%$ respectively, using a two-tailed test. 


\section{Table 6 \\ Differential litigation risk conditional on litigation triggers}

Panel A: Univariate analysis of litigation rate for firms with and without triggers

\begin{tabular}{l|ccc|ccc|ccc}
\hline Trigger: & Material restatement & & \multicolumn{3}{|c|}{ Missing management guidance } & Large price drop & \\
\hline & $\begin{array}{c}\text { Foreign } \\
\text { firms }\end{array}$ & $\begin{array}{c}\text { US matched } \\
\text { firms }\end{array}$ & $\begin{array}{c}\text { Diff. } \\
\text { [p-val] }\end{array}$ & $\begin{array}{c}\text { Foreign } \\
\text { firms }\end{array}$ & $\begin{array}{c}\text { US matched } \\
\text { firms }\end{array}$ & $\begin{array}{c}\text { Diff. } \\
\text { [p-val] }\end{array}$ & $\begin{array}{c}\text { Foreign } \\
\text { firms }\end{array}$ & $\begin{array}{c}\text { US matched } \\
\text { firms }\end{array}$ & $\begin{array}{c}\text { Diff. } \\
\text { [p-val] }\end{array}$ \\
\hline With & $15.85 \%$ & $7.63 \%$ & 0.08 & $6.23 \%$ & $6.24 \%$ & -0.00 & $7.98 \%$ & $10.22 \%$ & -0.02 \\
trigger & $(\mathrm{N}=82)$ & $(\mathrm{N}=249)$ & {$[0.06]$} & $(\mathrm{N}=305)$ & $(\mathrm{N}=1,186)$ & {$[0.99]$} & $(\mathrm{N}=764)$ & $(\mathrm{N}=1,047)$ & {$[0.10]$} \\
Without & $2.22 \%$ & $3.95 \%$ & -0.02 & $2.00 \%$ & $3.34 \%$ & -0.01 & $1.56 \%$ & $2.82 \%$ & -0.01 \\
trigger & $(\mathrm{N}=6,347)$ & $(\mathrm{N}=6,180)$ & {$[0.00]$} & $(\mathrm{N}=7,938)$ & $(\mathrm{N}=7,057)$ & {$[0.00]$} & $(\mathrm{N}=7,479)$ & $(\mathrm{N}=7,196)$ & {$[0.00]$}
\end{tabular}

Panel B: Multivariate analysis of litigation probability conditional on litigation triggers

\begin{tabular}{|c|c|c|c|}
\hline & $\begin{array}{c}1) \\
\text { Foreign \& US } \\
\text { matched firms }\end{array}$ & $\begin{array}{c}(2) \\
\text { Foreign \& US } \\
\text { matched firms }\end{array}$ & $\begin{array}{c}\text { (3) } \\
\text { Foreign \& US } \\
\text { matched firms }\end{array}$ \\
\hline Trigger & $\begin{array}{l}\text { Material } \\
\text { restatements } \\
\mathbf{0 . 7 0 * * *} \\
(0.009)\end{array}$ & $\begin{array}{c}\text { Missing management } \\
\text { guidance } \\
\mathbf{0 . 4 1} * * * \\
(0.004)\end{array}$ & $\begin{array}{l}\text { Large } \\
\text { price drop } \\
\mathbf{1 . 8 8} * * * \\
(0.000)\end{array}$ \\
\hline Fore ign indicator (a) & $\begin{array}{c}-\mathbf{0 . 6 2} * * * \\
(0.000)\end{array}$ & $\begin{array}{c}-\mathbf{- 0 . 5 8} * * * \\
(0.000)\end{array}$ & $\begin{array}{c}-\mathbf{0 . 7 0} * * * \\
(0.000)\end{array}$ \\
\hline Trigger $*$ Fore ign indicator (b) & $\begin{array}{c}1.40 * * * \\
(0.007)\end{array}$ & $\begin{array}{l}\mathbf{0 . 7 1} * * \\
(0.014)\end{array}$ & $\begin{array}{l}\mathbf{0 . 4 7 * *} \\
(0.039)\end{array}$ \\
\hline $\begin{array}{l}\text { Chi-Square test } \\
\text { (a) }+ \text { (b) }=0\end{array}$ & $\begin{array}{c}2.48 \\
(0.116)\end{array}$ & $\begin{array}{c}0.24 \\
(0.627)\end{array}$ & $\begin{array}{c}1.56 \\
(0.211)\end{array}$ \\
\hline \multicolumn{4}{|l|}{ Firm characteristics } \\
\hline FPS Industry & $\begin{array}{l}0.43^{* * *} \\
(0.001)\end{array}$ & $\begin{array}{l}0.43^{* * * *} \\
(0.000)\end{array}$ & $\begin{array}{l}0.53^{* * *} \\
(0.000)\end{array}$ \\
\hline Size $_{t-1}$ & $\begin{array}{l}0.31^{* * *} \\
(0.000)\end{array}$ & $\begin{array}{l}0.28 * * * \\
(0.000)\end{array}$ & $\begin{array}{l}0.33^{* * * *} \\
(0.000)\end{array}$ \\
\hline Sales growth ${ }_{t-1}$ & $\begin{array}{l}0.48^{* * *} \\
(0.000)\end{array}$ & $\begin{array}{l}0.47 * * * \\
(0.000)\end{array}$ & $\begin{array}{l}0.43^{* * * *} \\
(0.000)\end{array}$ \\
\hline Prior year return $\mathrm{t}-1$ & $\begin{array}{l}-0.22 * * \\
(0.029)\end{array}$ & $\begin{array}{l}-0.25^{* * *} \\
(0.009)\end{array}$ & $\begin{array}{l}-0.17^{*} \\
(0.051)\end{array}$ \\
\hline Prior return skewness t-1 & $\begin{array}{l}-0.25 * * * \\
(0.000)\end{array}$ & $\begin{array}{l}-0.22 * * * \\
(0.000)\end{array}$ & $\begin{array}{c}-0.21^{* * *} \\
(0.000)\end{array}$ \\
\hline Prior return volatility t-1 & $\begin{array}{c}20.78^{* * * *} \\
(0.000)\end{array}$ & $\begin{array}{c}19.90^{* * * *} \\
(0.000)\end{array}$ & $\begin{array}{l}7.23^{* *} \\
(0.023)\end{array}$ \\
\hline Prior year turnover $\mathrm{t}_{\mathrm{t}-1}$ & $\begin{array}{c}0.35^{* * * *} \\
(0.004)\end{array}$ & $\begin{array}{c}0.49^{* * *} \\
(0.000)\end{array}$ & $\begin{array}{c}0.54^{* * * *} \\
(0.000)\end{array}$ \\
\hline Constant & $\begin{array}{c}-6.46^{* * *} \\
(0.000)\end{array}$ & $\begin{array}{l}-6.32 * * * \\
(0.000)\end{array}$ & $\begin{array}{c}-6.21^{* * *} \\
(0.000)\end{array}$ \\
\hline Year FE & $\mathrm{Y}$ & $\mathrm{Y}$ & $\mathrm{Y}$ \\
\hline Observations & 12,858 & 16,486 & 16,486 \\
\hline Pseudo R-squared & 0.0805 & 0.0776 & 0.1272 \\
\hline
\end{tabular}


Notes: Panel A shows the percentage of firm-years with or without litigation triggers for both the foreign sample and the matched U.S. sample. Panel B reports the estimation from a logistic regression of equation (3). The dependent variable is an indicator variable that takes a value of 1 if the firm is sued in the particular year, 0 otherwise. We use three triggers:, (1) material restatement is equal to 1 if the firm files at least one restatement in the form of 6-k, 8-k or a press release in the fiscal year (before the filing date for a sued firm), and 0 otherwise; (2) missing management guidance is equal to 1 if the firm's previous-fiscal-yearend EPS fails to meet management guidance, and 0 otherwise; (3) large price drop is equal to 1 if the firm has at least one weekly return that is greater than negative $30 \%$ in the fiscal year (before the filing date for a sued firm), and 0 otherwise. The foreign indicator is equal to 1 for foreign cross-listed firms and 0 for U.S. firms. All other variables are defined in the appendix. Standard errors are clustered at the firm level. Significance is denoted by ***, **, and * for $1 \%, 5 \%$, and $10 \%$ respectively, using a two-tailed test. 


\section{Table 7}

\section{Litigation risk for foreign firms and transaction costs}

Panel A: The effect of home country geographic distance conditional on litigation triggers

\begin{tabular}{lccc}
\hline & $(1)$ & $(2)$ & $(3)$ \\
& Foreign firms & Foreign firms & Foreign firms \\
\hline Trigger & Material & Missing management & Large \\
& restatements & guidance & price drop \\
Trans action cost & $\mathbf{- 1 . 0 2}$ & $\mathbf{0 . 6 6}$ & $\mathbf{2 . 8 9}$ \\
& $(0.850)$ & $(0.823)$ & $(0.212)$ \\
Trigger $*$ Trans action cost & $\mathbf{- 0 . 3 3 * *}$ & $\mathbf{- 0 . 3 5 * *}$ & $(0.084)$ \\
& $(0.022)$ & $(0.012)$ & $\mathbf{- 0 . 0 5}$ \\
Firm controls & $\mathbf{0 . 3 5}$ & $\mathbf{0 . 0 4}$ & $(0.843)$ \\
Year FE & $(0.570)$ & $(0.911)$ & Y \\
Observations & $\mathrm{Y}$ & $\mathrm{Y}$ & $\mathrm{Y}$ \\
Pseudo R-squared & $\mathrm{Y}$ & $\mathrm{Y}$ & 8,243 \\
\hline Panel B: The effect of home country judicial efficiency conditional on litigation triggers
\end{tabular}

(1)

Foreign firms
(2)

Foreign firms
(3)

Foreign firms

$$
\text { Large }
$$

price drop

guidance

1.72

(0.507)

5.79***

(0.000)

$0.36 * * *$

(0.003)

(0.10)

-0.36**

(0.029)

(0.771)

$\mathrm{Y}$

$\mathrm{Y}$

$\mathrm{Y}$

$\mathrm{Y}$

$\begin{array}{ll}\mathrm{Y} & \mathrm{Y} \\ 5,069 & 635\end{array}$

0.0795
6,635

0.1389 0.0828

Pseudo R-squared

(1)

Foreign firms

Trigger

Trigger $*$ Transaction cost

Firm controls

Year FE

Observations

Pseudo R-squared
Foreign firms

Missing management

restatements

\subsection{2}

(0.394)

0.20***

(0.006)

0.07

(0.825)

$\mathrm{Y}$

$\mathrm{Y}$

5,856

0.0694 guidance

1.24

$(0.463)$

$0.21 * * *$

(0.003)

$\mathbf{- 0 . 0 3}$

(0.911)

$\mathrm{Y}$

$\mathrm{Y}$

7,498

0.0626
Foreign firms

Large

price drop

2.09**

(0.017)

0.15*

(0.057)

0.05

(0.710)

$\mathrm{Y}$

$\mathrm{Y}$

7,498

0.1216 
Notes: This table reports the estimation from a logistic regression of equation (4) for three transaction cost variables: geographic distance (Panel A), judicial efficiency (Panel B), and U.S. acquisitions in the home country (Panel C). The dependent variable is an indicator variable that takes a value of 1 if the firm is sued in that particular year, 0 otherwise. In each panel, three triggers are used: material restatements, missing management guidance, and large price drop. All other variables are defined in the appendix. Standard errors are clustered at the firm level. Significance is denoted by $* * *, * *$, and $*$ for $1 \%, 5 \%$, and $10 \%$ respectively, using a two-tailed test. 
Table 8

Resolution of litigations against foreign and U.S. matched firms

\begin{tabular}{lccc}
\hline & (1) Dimissal & (2) Settlement speed & (3) Settlement amount \\
\hline Fore ign indicator & 0.21 & $0.65^{* *}$ & 0.37 \\
GAAP & $(0.459)$ & $(0.020)$ & $(0.182)$ \\
& $-0.88^{* * *}$ & 1.23 & 0.22 \\
Sec 11 & $(0.002)$ & $(0.302)$ & $(0.415)$ \\
& $-0.64^{*}$ & 0.89 & $1.01^{* * *}$ \\
Lead Institution Plaintiff & $(0.062)$ & $(0.577)$ & $(0.001)$ \\
& $-0.55^{*}$ & 0.88 & $0.81^{* * *}$ \\
Log(Class Period) & $(0.0523$ & $(0.470)$ & $(0.003)$ \\
Class Period Price Drop & -0.22 & 0.92 & $0.43^{* * *}$ \\
Size & $(0.129)$ & $(0.274)$ & $(0.003)$ \\
Sales Growth & -0.40 & 0.61 & -0.42 \\
FPS Industry & $(0.549)$ & $(0.229)$ & $(0.427)$ \\
Turnover & 0.08 & 0.98 & $0.30^{* * *}$ \\
& $(0.269)$ & $(0.650)$ & $(0.000)$ \\
Observations & 0.25 & $1.45^{* *}$ & 0.05 \\
Pseudo R-squared & $(0.649)$ & $(0.020)$ & $(0.873)$ \\
& -0.16 & 1.26 & -0.18 \\
& $(0.581)$ & $(0.253)$ & $(0.528)$ \\
& -3.40 & 2.98 & 5.70 \\
& $(0.358)$ & $(0.234)$ & $(0.127)$ \\
& & & 136 \\
& 252 & 136 & $($ Adj.) 0.2929 \\
\hline
\end{tabular}

This table reports the regression results based on equation (5) for the analysis of dismissal likelihood, settlement speed, and settlement amount in a sample of 126 litigation cases against foreign cross-listed firms and their matched U.S. sample. The U.S. sample is matched to the foreign lawsuit sample on year, FPS industry membership, and firm size. In column (1), the model specification is logistic and the dependent variable is equal to 1 if a lawsuit is dismissed, 0 otherwise. Column (2) shows results based on a Cox proportional hazard model where the dependent variable is the number of days between the lawsuit filing date and its settlement date. Column (3) reports the OLS results where the dependent variable is the log total dollar amount of the settlement. The last two columns include only 68 settled cases against foreign firms and 68 matched U.S. cases (also matching on year, FPS industry membership, and firm size). The foreign indicator is equal to 1 for foreign cross-listed firms and 0 for U.S. firms. All other variables are defined in the appendix. Standard errors are clustered at the firm level. Significance is denoted by ${ }^{* * *},{ }^{* *}$, and $*$ for $1 \%, 5 \%$, and $10 \%$ respectively, using a two-tailed test. 


\section{Table 9}

Sensitivity analysis: Alternative definition of foreign firms

\begin{tabular}{|c|c|c|c|}
\hline & $\begin{array}{l}\text { (1) } \\
\text { Foreign \& US } \\
\text { matched firms }\end{array}$ & $\begin{array}{l}(2) \\
\text { Foreign \& US } \\
\text { matched firms }\end{array}$ & $\begin{array}{l}\text { (3) } \\
\text { Foreign \& US } \\
\text { matched firms }\end{array}$ \\
\hline Trigger & $\begin{array}{c}\text { Material } \\
\text { restatements } \\
\mathbf{0 . 6 2 * *} \\
(0.032)\end{array}$ & $\begin{array}{c}\text { management } \\
\text { guidance } \\
\mathbf{0 . 3 7 * *} \\
(0.014)\end{array}$ & $\begin{array}{l}\text { Large } \\
\text { price drop } \\
1.93^{* * *} \\
(0.000)\end{array}$ \\
\hline Foreign indicator (a) & $\begin{array}{c}-\mathbf{0 . 7 8} * * * \\
(0.000)\end{array}$ & $\begin{array}{c}-\mathbf{0 . 7 9} * * * \\
(0.000)\end{array}$ & $\begin{array}{c}-\mathbf{0 . 8 8} * * * \\
(0.000)\end{array}$ \\
\hline Trigger * Foreign indicator (b) & $\begin{array}{l}1.46 * * \\
(0.034)\end{array}$ & $\begin{array}{c}\mathbf{0 . 8 6} * * * \\
(0.008)\end{array}$ & $\begin{array}{l}\text { 0.43* } \\
(0.099)\end{array}$ \\
\hline $\begin{array}{l}\text { Chi-Square test } \\
(\mathrm{a})+(\mathrm{b})=0\end{array}$ & $\begin{array}{c}1.04 \\
(0.308)\end{array}$ & $\begin{array}{c}0.06 \\
(0.806)\end{array}$ & $\begin{array}{l}4.39 * * \\
(0.036)\end{array}$ \\
\hline Firm characteristics & & & \\
\hline FPS Industry & $\begin{array}{l}0.47^{* * *} \\
(0.001)\end{array}$ & $\begin{array}{c}0.48 * * * \\
(0.000)\end{array}$ & $\begin{array}{c}0.59 * * * \\
(0.000)\end{array}$ \\
\hline Size $t-1$ & $\begin{array}{c}0.33^{* * *} \\
(0.000)\end{array}$ & $\begin{array}{l}0.31^{* * *} \\
(0.000)\end{array}$ & $\begin{array}{l}0.36 * * * \\
(0.000)\end{array}$ \\
\hline Sales growth $\mathrm{t}-1$ & $\begin{array}{l}0.55^{* * *} \\
(0.000)\end{array}$ & $\begin{array}{l}0.53^{* * *} \\
(0.000)\end{array}$ & $\begin{array}{l}0.49 * * * \\
(0.000)\end{array}$ \\
\hline Prior year return $\mathrm{t}-1$ & $\begin{array}{l}-0.30^{* *} \\
(0.010)\end{array}$ & $\begin{array}{c}-0.29 * * * \\
(0.005)\end{array}$ & $\begin{array}{l}-0.21^{* *} \\
(0.034)\end{array}$ \\
\hline Prior return skewness ${ }_{t-1}$ & $\begin{array}{c}-0.27 * * * \\
(0.000)\end{array}$ & $\begin{array}{c}-0.23^{* * *} \\
(0.000)\end{array}$ & $\begin{array}{c}-0.22^{* * *} \\
(0.000)\end{array}$ \\
\hline Prior return volatility $\mathrm{t}-1$ & $\begin{array}{c}20.73^{* * * *} \\
(0.000)\end{array}$ & $\begin{array}{c}19.92^{* * * *} \\
(0.000)\end{array}$ & $\begin{array}{c}6.73^{*} \\
(0.057)\end{array}$ \\
\hline Prior year turnover ${ }_{t-1}$ & $\begin{array}{l}0.38^{* * *} \\
(0.004)\end{array}$ & $\begin{array}{l}0.50 * * * \\
(0.000)\end{array}$ & $\begin{array}{l}0.55^{* * *} \\
(0.000)\end{array}$ \\
\hline Constant & $\begin{array}{c}-6.76^{* * *} \\
(0.000)\end{array}$ & $\begin{array}{c}-6.65 * * * \\
(0.000)\end{array}$ & $\begin{array}{c}-6.54^{* * *} \\
(0.000)\end{array}$ \\
\hline Year FE & $\mathrm{Y}$ & $\mathrm{Y}$ & $\mathrm{Y}$ \\
\hline Observations & 11,124 & 14,278 & 14,278 \\
\hline Pseudo R-squared & 0.095 & 0.093 & 0.142 \\
\hline
\end{tabular}

Table 9 reports the estimation from a logistic regression of equation (3) for only a more restricted definition of foreign firms: companies that are headquartered in the U.S. but incorporated in other countries are dropped from the foreign sample, as well as their matched U.S. counterparts. As in Table 6, the dependent variable is an indicator variable that takes a value of 1 if the firm is sued in the particular year, 0 otherwise. We use three triggers:. material restatements, missing management guidance, and large price drop. All other variables are defined in the appendix. Standard errors are clustered at the firm level. Significance is denoted by ***, **, and * for $1 \%, 5 \%$, and $10 \%$ respectively, using a two-tailed test. 